\title{
Reduction and oxidation kinetics of Tierga iron ore for Chemical Looping Combustion with diverse fuels
}

T. Mendiara, A. Abad*, L. F. de Diego, F. García-Labiano, P. Gayán, J. Adánez

Department of Energy and Environment, Instituto de Carboquímica-ICB-CSIC

Miguel Luesma Castán 4, 50018, Zaragoza, Spain

abad@icb.csic.es

* Corresponding author:

Phone: + 34976733 977;

Fax: +34976733 318

\begin{abstract}
The in-situ Gasification Chemical Looping Combustion (iG-CLC) process allows combustion with inherent $\mathrm{CO}_{2}$ capture. In this process, the oxygen for combustion is commonly supplied by a solid oxygen carrier based on a metal oxide thus avoiding direct contact between fuel and air. The oxygen carrier circulates between two reactors. In the fuel reactor, the fuel is oxidized to $\mathrm{CO}_{2}$ and $\mathrm{H}_{2} \mathrm{O}$ while the oxygen carrier is reduced. In the air reactor, the reduced oxygen carrier is regenerated in air. Ilmenite has been widely used as a low-cost oxygen carrier for the $i \mathrm{G}-\mathrm{CLC}$ process, and it can be taken as a reference material. Recently, the Tierga iron ore has been identified as a promising candidate for further scale-up of the process due to the higher combustion efficiency achieved compared to the results using
\end{abstract}


ilmenite. Modelling of the iG-CLC process with Tierga iron ore as oxygen carrier is a key step to determine the potential of this material. In order to model the $i \mathrm{G}-\mathrm{CLC}$ process it is necessary to know the reactivity of both oxygen carrier and fuel used. In this paper, the kinetic determination for the reduction and oxidation reactions of the Tierga ore is presented. Reaction orders close to unity were obtained for the main reducing gases, i.e. $\mathrm{H}_{2}, \mathrm{CO}$ and $\mathrm{CH}_{4}$, as well as $\mathrm{O}_{2}$. The activation energy values obtained were $81.1 \pm 7,76.1 \pm 6$ and $257 \pm 14$ $\mathrm{kJ} / \mathrm{mol}$ for $\mathrm{H}_{2}, \mathrm{CO}$ and $\mathrm{CH}_{4}$, respectively. The activation energy for oxidation was determined as $18.4 \pm 05 \mathrm{~kJ} / \mathrm{mol}$. In addition, a simple method is used for a comparison of the performance of different oxygen carriers based on their kinetics.

Keywords: $\mathrm{CO}_{2}$ capture; combustion; coal; chemical looping; iron ore; kinetics 


\section{Introduction}

Chemical Looping Combustion (CLC) is a $\mathrm{CO}_{2}$ capture technology in which the oxygen needed for combustion is provided by an oxygen carrier (OC) instead of air as in conventional combustion [1]. The oxygen carrier circulates between two reactors (Figure 1). The oxygen carrier is normally a metal oxide that is reduced in the fuel reactor while the fuel is oxidized to $\mathrm{CO}_{2}$ and $\mathrm{H}_{2} \mathrm{O}$. Once the steam is condensed, the product gas from the fuel reactor is a highly- $\mathrm{CO}_{2}$ concentrated stream. The reduced oxygen carrier is then transported to the air reactor where it is oxidized in air to start a new redox cycle. If the fuel to be burned is a solid fuel, one of the CLC configurations adopted is the in Situ Gasification Chemical Looping Combustion ( $i \mathrm{G}-\mathrm{CLC}$ ) [2]. In this approach, the solid fuel is first gasified in the fuel reactor by steam $/ \mathrm{CO}_{2}$ and then the gasification products react with the oxygen carrier particles to produce $\mathrm{CO}_{2}$ and $\mathrm{H}_{2} \mathrm{O}$.

In $i \mathrm{G}-\mathrm{CLC}$, low-cost oxygen carriers are preferred as they present important advantages for this process. The combustion of solid fuels generates ashes that can accumulate in the $i \mathrm{G}$ CLC system leading to operational problems. Therefore their periodic drainage is necessary in order to avoid their accumulation. In the drainage, some oxygen carrier particles can be lost together with the ashes. Therefore, the oxygen carrier should be as inexpensive as possible. In addition to cheap oxygen carriers, $i \mathrm{G}-\mathrm{CLC}$ of solid fuels requires the use of widely available and reactive materials as oxygen carriers [3]. Ilmenite, a mineral based on $\mathrm{FeTiO}_{3}$, has been the most widely used Fe-based mineral in most of the $i \mathrm{G}$-CLC units in operation due to its adequate reactivity, good fluidization behaviour and physical stability [2]. More recently, the use of a highly reactive iron ore material (Tierga ore) has shown improved performance for coal and biomass compared to the widely used ilmenite particles [4-6]. The use of Tierga iron ore as oxygen carrier resulted in combustion efficiency values higher than those obtained with ilmenite in both $0.5 \mathrm{~kW}$ and $100 \mathrm{~kW}$ CLC units with coal $[4,7]$. 
An oxygen carrier must have enough reactivity to achieve a high conversion of the fuel in the fuel reactor, and to be oxidized again in the air reactor. The reactivity of the oxygen carrier, together with its oxygen transport capacity, determine the solids inventories needed in fuel and air reactors as well as the recirculation rate of the oxygen carrier between the reactors [8]. Both the solids inventories and the recirculation rate are key parameters for the design of a chemical looping system. Modeling of fuel and air reactors is a powerful tool in order to calculate the solids inventory required in a chemical looping process with coal [9-17]. Mathematical models require the knowledge of the kinetics of the reactions between oxygen carrier and gases present in the fuel and air reactors. During the last years, most of the research on kinetics of low-cost oxygen carriers for the $i \mathrm{G}$-CLC process was focused on Febased materials. Most of the kinetic studies that can be found in literature on Fe-based oxygen carriers refer to synthetic materials (supported or unsupported $\mathrm{Fe}_{2} \mathrm{O}_{3}$ ) [18-26]. Most of these studies consider the reduction from $\mathrm{Fe}_{2} \mathrm{O}_{3}$ not only to $\mathrm{Fe}_{3} \mathrm{O}_{4}$, which would be the most interesting for $i \mathrm{G}-\mathrm{CLC}$ purposes [27], but also the further reduction to $\mathrm{FeO} / \mathrm{Fe}$. Less are the studies addressing the determination of the kinetic parameters for Fe-based minerals or industrial residues for CLC. Kinetic parameters for the reactions with ilmenite have been determined by several authors [28-30]. Recently, kinetic studies referred to iron ores used as oxygen carriers were performed [31-35]. These are mostly focused on one of the reducing gases present in the fuel reactor atmosphere (mostly methane or hydrogen) and the effect of gas concentration and temperature is not analyzed in all the cases. Thus, the range of operating conditions relevant to the $i \mathrm{G}$-CLC process are not covered. Luo et al. [31] reported activation energies in the reduction with methane between 49 and $184 \mathrm{~kJ} / \mathrm{mol}$. Nasr and Plucknett [32] reported $215 \mathrm{~kJ} / \mathrm{mol}$ for the reduction of $\mathrm{Fe}_{2} \mathrm{O}_{3}$ to $\mathrm{Fe}_{3} \mathrm{O}_{4}$ with methane. In a study performed by Ksepko et al. [35] with an Fe-based ore, the activation energy obtained for the reduction reaction with methane was $42 \mathrm{~kJ} / \mathrm{mol}$ and the reaction order 1.98 . In the 
same study, oxidation kinetics was determined $(16.7 \mathrm{~kJ} / \mathrm{mol}$ as activation energy and 0.49 as reaction order).

The potential of Tierga iron ore to improve the combustion efficiency in the $i \mathrm{G}$-CLC process can be determined by modelling of the process, in a similar way that it was done previously with ilmenite [9-12]. In order to include this material in the simulations of the $i \mathrm{G}$-CLC process, the determination of the kinetic parameters of the Tierga ore under conditions relevant for the process should be accomplished.

In this paper, the determination of the detailed reaction kinetics of the reduction and oxidation reactions of the mentioned Tierga iron ore particles will be presented using a proper gas-solid reaction model. A simple model is used for evaluation of different low-cost oxygen carriers for the $i \mathrm{G}$-CLC process. This model is especially useful for a first screening step in the development of oxygen carriers. The model facilitates the evaluation of the suitability of an oxygen carrier avoiding the need of a computational model. With this model, solids inventory calculations using the obtained kinetic parameters will be done and compared with calculations performed with other low-cost oxygen carriers.

\section{Material and methods}

\subsection{Tierga iron ore}

A mineral from a hematite mine in Tierga (Zaragoza, Spain) was tested. It was crushed and sieved to the desired size $(+100-300 \mu \mathrm{m})$. Table 1 shows the main physical and chemical properties of these particles. The main solid phases identified by XRD diffraction were hematite $\left(\mathrm{Fe}_{2} \mathrm{O}_{3}\right)$, dolomite $\left(\mathrm{CaMg}\left(\mathrm{CO}_{3}\right)_{2}\right)$ and $\mathrm{SiO}_{2}$. Then it was calcined at $1223 \mathrm{~K}$ for 12 hours, in order to decompose the dolomite impurities present in the sample to $\mathrm{CaO}$ and $\mathrm{MgO}$ and to increase the mechanical strength. A high value of crushing strength was observed. The iron ore presented a high $\mathrm{Fe}_{2} \mathrm{O}_{3}$ content (76.5 wt.\%). 
Tierga iron ore was evaluated for its use as oxygen carrier in $i G$-CLC with coal both in a batch fluidized bed reactor [36] and in continuously operated CLC units [4, 7]. As it is shown in Table 1, Tierga iron ore particles showed some changes in its chemical and physical properties after calcination process and redox cycles. Initially, $\mathrm{CaO}$ and $\mathrm{MgO}$ were present in the outer surface in the calcined particles [4]. However, these compounds were removed after operation in a CLC unit, and the $\mathrm{Fe}_{2} \mathrm{O}_{3}$ content increased from 76.5 to 83.5 wt.\%. Also, porosity decreased somewhat, but other physical properties were barely varied.

\subsection{Experimental setup and procedure}

The effect of the main operating variables (reacting atmosphere and temperature) on the oxidation and reduction rates of Tierga iron ore particles was determined by thermogravimetric analysis (TGA) in a CI Electronics type apparatus. Figure 2 shows a scheme of the experimental set-up. Details about it can be found elsewhere [37]. The sample weight used for the experiments was about $50 \mathrm{mg}$. The oxygen carrier particles were heated up to the desired temperature in an air atmosphere. Once the set temperature was reached, several redox cycles were performed by alternating reduction (with $\mathrm{H}_{2}, \mathrm{CO}$ or $\mathrm{CH}_{4}$ ) and oxidation conditions (air or diluted air).

It must be considered that Tierga iron ore should react with gaseous reducing agents e.g. $\mathrm{H}_{2}$, $\mathrm{CO}$ and $\mathrm{CH}_{4}$. These gases are main components on solid fuel gasification. They will be found in different concentrations throughout the fuel reactor. Thus, reduction reaction was carried out with several $\mathrm{H}_{2}, \mathrm{CO}$ or $\mathrm{CH}_{4}$ concentration values ranging from 5 to $60 \mathrm{vol} \%$. The effect of $\mathrm{H}_{2} \mathrm{O}$ concentration during reduction with $\mathrm{H}_{2}$ or $\mathrm{CH}_{4}$, as well as the $\mathrm{CO}_{2}$ effect on reduction with $\mathrm{CO}$, was also analysed. Moreover, during oxidation, the $\mathrm{O}_{2}$ concentration will vary from $21 \%$ at the inlet to about $4 \%$ at the outlet, depending on the excess air used for the reaction. So, oxygen concentration values between 5 and 21 vol\% were used. In order to avoid the 
mixing of combustible gas and air, nitrogen was introduced for two minutes between the oxidizing and the reducing periods. At the beginning, Tierga iron ore particles were fully oxidized. In fact, to analyze the reactivity of the oxidation reaction it was necessary to reduce the sample first. This initial reduction step was carried out at $1073 \mathrm{~K}$ in an atmosphere composed of $5 \mathrm{vol} \% \mathrm{H}_{2}$ and $40 \mathrm{vol} \% \mathrm{H}_{2} \mathrm{O}\left(\mathrm{N}_{2}\right.$ to balance). At these conditions the reduction of free $\mathrm{Fe}_{3} \mathrm{O}_{4}$ towards $\mathrm{FeO}$ was avoided. Thus, Tierga iron ore particles ready to be oxidized were composed by $\mathrm{Fe}_{3} \mathrm{O}_{4}$ because neither $\mathrm{FeO}$ nor $\mathrm{Fe}$ was formed. In this way, the redox cycles between $\mathrm{Fe}_{2} \mathrm{O}_{3}$ and $\mathrm{Fe}_{3} \mathrm{O}_{4}$ existing in the fuel reactor were simulated in the TGA unit. When the environment conditions allowed reduction to $\mathrm{FeO}$ or even to $\mathrm{Fe}$, e.g. for high fuel gas concentration, only mass loss from $\mathrm{Fe}_{2} \mathrm{O}_{3}$ to $\mathrm{Fe}_{3} \mathrm{O}_{4}$ was considered for kinetic determination. Thus, the following chemical reactions were considered:

$$
\begin{aligned}
& 3 \mathrm{Fe}_{2} \mathrm{O}_{3}+\mathrm{H}_{2} \longrightarrow 2 \mathrm{Fe}_{3} \mathrm{O}_{4}+\mathrm{H}_{2} \mathrm{O} \\
& 3 \mathrm{Fe}_{2} \mathrm{O}_{3}+\mathrm{CO} \longrightarrow 2 \mathrm{Fe}_{3} \mathrm{O}_{4}+\mathrm{CO}_{2} \\
& 12 \mathrm{Fe}_{2} \mathrm{O}_{3}+\mathrm{CH}_{4} \longrightarrow 8 \mathrm{Fe}_{3} \mathrm{O}_{4}+\mathrm{CO}_{2}+2 \mathrm{H}_{2} \mathrm{O} \\
& 4 \mathrm{Fe}_{3} \mathrm{O}_{4}+\mathrm{O}_{2} \longrightarrow 6 \mathrm{Fe}_{2} \mathrm{O}_{3}
\end{aligned}
$$

Reduction and oxidation reactions were carried out at temperatures in the 1073-1273 K interval. The temperature in the reaction zone can greatly affect to the reaction rate and it was carefully checked. Deviations lower than $2 \mathrm{~K}$ were found in all cases during the reaction period.

TGA experiments allowed to analyze the reactivity of the oxygen carriers under well-defined conditions, and in the absence of complex fluidizing factors such as those derived from particle attrition and inter-phase mass transfer processes. To establish whether external film mass transfer, inter-particle diffusion and/or intra-particle diffusion were affecting the reaction rate, the gas flow rate, the sample mass and the particle size were varied in the range 4-15 $\mathrm{cm}^{3} \mathrm{~s}^{-1} \mathrm{STP}$, from 10 to $150 \mathrm{mg}$ and from 40 to $300 \mu \mathrm{m}$, respectively. It was observed 
that the reaction rate was not affected by these parameters, indicating that diffusional processes were not of importance at the conditions used in the TGA tests. Besides, the crucible used in the experiments was specifically designed to minimize problems of gas diffusion in the crucible that can be usually encountered in TGA apparatus [38]. The crucible was made of a wire-mesh of Platinum (14 mm diameter and $8 \mathrm{~mm}$ height). So, the gas flow is able to pass through the mesh, avoiding the stagnant area usually present in solid crucibles. Moreover, previous studies showed that oxygen carrier particles can be considered isothermal during reduction or oxidation [39].

\subsection{Data evaluation}

The conversion level of the oxygen carrier was calculated for the reduction $\left(X_{\text {red }}\right)$ and oxidation $\left(X_{o x}\right)$ reactions from the instantaneous mass, $m$, registered in the TGA as

$$
\begin{aligned}
& X_{r e d}=\frac{m_{o x}-m}{R_{O C} m_{o x}} \\
& X_{o x}=1-X_{r e d}=\frac{m-m_{r e d}}{R_{O C} m_{o x}}
\end{aligned}
$$

\section{Results and Discussion}

The reactivity of Tierga iron ore particles as received, calcined and after coal combustion in a CLC unit was analyzed by TGA experiments at $1223 \mathrm{~K}$ with 15 vol $\% \mathrm{H}_{2}$; see Figure 3 . The solid line corresponds to conversion vs. time curve obtained for Tierga ore as received, i.e. without being calcined. The dotted line represents the corresponding result for a sample which has been calcined in air at $1223 \mathrm{~K}$ during $12 \mathrm{~h}$. It can be observed that the reactivity of the sample clearly decreased after the calcination process. The dashed line shows the results using a sample extracted from a continuous $500 \mathrm{~W}_{\text {th }}$ unit after 30 hours coal combustion. In this case, the reactivity of the sample was higher than that corresponding to the calcined 
sample, but also higher than that corresponding to the fresh sample. This activation process observed for the Tierga ore has been reported earlier $[4,36]$. The Tierga ore experienced a gain in reactivity after successive redox cycles. As a conclusion, reactivity of Tierga ore material varied during calcination and activation processes to eventually stabilise to a relatively high reactivity value after redox cycles, which was found both in batch fluidized bed reactor and in a CLC unit $[4,36]$. Therefore, kinetics of particles in the transition periods, i.e. calcined or non-fully activated particles, was not determined due to its uncertainty in the reactivity variability when these particles were exposed to additional redox cycles. Otherwise, kinetics of Tierga ore particles previously activated in a $0.5 \mathrm{~kW}_{\text {th }}$ CLC unit was determined in this work. The Tierga iron ore was used for $90 \mathrm{~h}$ to burn coal and biomass at temperatures in the $1148-1258 \mathrm{~K}$ in the fuel reactor and $1223 \mathrm{~K}$ in the air reactor, and limiting the reduction degree to $\mathrm{Fe}_{3} \mathrm{O}_{4}[4,6]$. Initially, it was determined that reactivity of the oxygen carrier particles corresponded to that of activated particles, and five redox cycles were carried out in order to evaluate the variations in the reactivity observed in the TGA. As expected, the reaction rate was unchanged during the five redox cycles, and the fifth cycle was used for kinetic determination.

\subsection{Kinetic determination for the reduction reaction with $\mathrm{H}_{2}, \mathrm{CO}$ and $\mathrm{CH}_{4}$}

In the fuel reactor of the $i G$-CLC system, the oxygen carrier is reduced by the fuel gas, which will be composed mainly $\mathrm{H}_{2}, \mathrm{CO}$ and volatile compounds proceeding from coal pyrolysis. Therefore, the kinetic parameters were obtained for reduction with $\mathrm{H}_{2}$ and $\mathrm{CO}$ as main products of coal gasification, and $\mathrm{CH}_{4}$ as a representative gaseous compound from coal pyrolysis. To determine the kinetic parameters of the reduction reaction of Tierga iron ore, several experiments at different temperatures (1073, 1123, 1173, 1223 and $1273 \mathrm{~K})$ and gas concentrations $(5,15,30$ and 60 vol\%) were carried out. 


\subsubsection{Effect of gas product content on the reduction reaction}

To analyze the effect of the gas product on the reaction rate of the Tierga iron ore, several experiments were done varying the ratio $\mathrm{H}_{2} \mathrm{O} / \mathrm{H}_{2}$ or $\mathrm{CO}_{2} / \mathrm{CO}$ during the reduction stage. Thus, tests were done at $1223 \mathrm{~K}$ with $5 \mathrm{vol} \% \mathrm{H}_{2}$ or $\mathrm{CO}$ and $\mathrm{H}_{2} \mathrm{O}$ or $\mathrm{CO}_{2}$ content from 0 to 40 vol\%, respectively. Figure 4 shows the weight-loss curves obtained. It can be seen that during the first $\approx 60-70$ seconds, the reaction rate was not affected by the gas product content, i.e. $\mathrm{H}_{2} \mathrm{O}$ during reduction with $\mathrm{H}_{2}$ or $\mathrm{CO}_{2}$ during reduction with $\mathrm{CO}$. The weight loss observed during this time was assigned to the reduction of $\mathrm{Fe}_{2} \mathrm{O}_{3}$ and to $\mathrm{Fe}_{3} \mathrm{O}_{4}$, which corresponded to a mass loss of around $2.8 \mathrm{wt} \%$. This reaction has a high value of the equilibrium constant and the gas product concentration does not affect the reduction rate by thermodynamic considerations; see Table 2, and it is the only reaction considered for CLC using fluidized bed reactors [27]. However, the subsequent reaction is clearly affected by the gas product content: a higher amount of $\mathrm{H}_{2} \mathrm{O}$ or $\mathrm{CO}_{2}$ in the reacting gases leads to a lower reaction rate with $\mathrm{H}_{2}$ or $\mathrm{CO}$, respectively. This reaction corresponds to the reduction of $\mathrm{Fe}_{3} \mathrm{O}_{4}$ to $\mathrm{FeO}$, or even $\mathrm{Fe}$, which is dependent on the $\mathrm{H}_{2} \mathrm{O}$ or $\mathrm{CO}_{2}$ concentration at equilibrium conditions. Indeed, the reaction should not proceed for ratios $\mathrm{H}_{2} \mathrm{O} / \mathrm{H}_{2}>4.2$ or $\mathrm{CO}_{2} / \mathrm{CO}>2.8$, corresponding to $\mathrm{H}_{2} \mathrm{O}$ content higher than 20 vol\% or $\mathrm{CO}_{2}$ content higher than 15 vol\%, as it can be seen in Figure 4. At these high $\mathrm{H}_{2} \mathrm{O} / \mathrm{H}_{2}$ ratios, the final solid product is $\mathrm{Fe}_{3} \mathrm{O}_{4}$, corresponding to the value $R_{O C}=2.8 \mathrm{wt} \%$ previously calculated for Tierga iron ore.

In CLC complete combustion of fuel is desired. Therefore, only reduction to $\mathrm{Fe}_{3} \mathrm{O}_{4}$ can be exploited in a fluidized bed reactor; otherwise, unburnt compounds will be always present in the flue gases because of thermodynamic restrictions; see Table 2. Therefore, conversion vs. time curves for kinetic determination were calculated from the weight-loss loss showed in these curves at different conditions (gas composition and temperature) using $R_{O C}=2.8 \mathrm{wt} \%$ 
in equations (5) and (6). In these cases, only the part of the curve corresponding to the reduction to $\mathrm{Fe}_{3} \mathrm{O}_{4}$ was used, which was scarcely affected by the product gas concentration. Conversions higher than $100 \%$ could be obtained in experiments when $\mathrm{H}_{2} \mathrm{O} / \mathrm{H}_{2}$ or $\mathrm{CO}_{2} / \mathrm{CO}$ ratio was lower than equilibrium constant because further reduction of $\mathrm{Fe}_{3} \mathrm{O}_{4}$ to $\mathrm{FeO}$ could happen. However, the reduction to $\mathrm{FeO}$ was limited by changing the reacting atmosphere to $\mathrm{N}_{2}$ when all $\mathrm{Fe}_{2} \mathrm{O}_{3}$ was reduced to $\mathrm{Fe}_{3} \mathrm{O}_{4}$.

\subsubsection{Effect of fuel gas concentration}

To determine the effect of the gas concentration on the kinetics of the reduction reaction, several experiments at $1223 \mathrm{~K}$ and gas concentrations $(5,15,30$ and $60 \mathrm{vol} \%)$ were carried out. Figures 5(a-c) show plots of the effect of fuel gas concentration on the conversion-time curves obtained during reduction with $\mathrm{H}_{2}, \mathrm{CO}$ and $\mathrm{CH}_{4}$, respectively. It can be observed that an increase in the fuel gas concentration produces an increase in the reaction rate.

\subsubsection{Effect of reacting temperature}

The effect of temperature on the reaction rate of Tierga iron ore was later investigated. Figure 6(a-c) shows the conversion vs. time curves for reduction with 5 vol\% either $\mathrm{H}_{2}, \mathrm{CO}$ or $\mathrm{CH}_{4}$. For $\mathrm{H}_{2}$ and $\mathrm{CH}_{4}$, the reaction rate was quite affected by the temperature. An increase of temperature produces an increase in the reduction rate. However, reduction with $\mathrm{CO}$ was barely affected. More in detail, the reduction rate increased from 1073 to $1173 \mathrm{~K}$, but later lower conversion values were reached when temperature was increased above $1223 \mathrm{~K}$. This fact suggests a change in the relevance of different controlling step, e.g. chemical reaction or diffusion through product layer, as the reduction proceeded. 


\subsubsection{Determination of the kinetic parameters for reduction reactions}

The requirements that must fulfill a kinetic model are to be a representation as near as possible to the real process and that can be coupled without many difficulties with the fluidized bed reactor model. The grain model with uniform reaction in the particle has been often used for these purposes. The model assumes that the particle consists of a number of nonporous grains of uniform size $[40,41]$. The reaction proceeds in the grains following the shrinking core model (SCM). Thus, in the experiments were the reaction could be stopped in the reduction of $\mathrm{Fe}_{2} \mathrm{O}_{3}$ to $\mathrm{Fe}_{3} \mathrm{O}_{4}$, the slope of the conversion vs. time curves decreases as the conversion approach to the unity, in agreement with the SCM. However, in certain cases the conversion vs. time curves have near constant slope even for high conversion values. These cases were characterized by a further reduction of $\mathrm{Fe}_{3} \mathrm{O}_{4}$ due to a high concentration of the reducing gas used in the TGA. This difference in the conversion vs. curves at high conversion values is shown in Figure 4. However, further reduction of $\mathrm{Fe}_{3} \mathrm{O}_{4}$ is not suitable in CLC in order to allow a high conversion of the fuel to $\mathrm{CO}_{2}$ and $\mathrm{H}_{2} \mathrm{O}$ [27]. Therefore, the tendency to overcome conversion values higher than the unity was not considered to evaluate the quality of the kinetic determination.

The following kinetic model was assumed to interpret the experimental observations. Thus, it was assumed that Tierga ore particles were composed by grains with spherical shape. When required, mixed chemical reaction and diffusion through the product layer were considered as the relevant steps in the reduction reaction. The conversion-time dependence was the following:

$t=\tau_{c h}\left[1-\left(1-X_{r e d}\right)^{1 / 3}\right]+\tau_{p l}\left[1-3\left(1-X_{r e d}\right)^{2 / 3}+2\left(1-X_{r e d}\right)\right]$

$\tau_{\mathrm{ch}}$ and $\tau_{\mathrm{pl}}$ the time for complete conversion for only chemical reaction or diffusion through product layer control. 


$$
\tau_{c h}=\frac{\rho_{m} r_{g}}{b k_{s} C_{i}^{n}}
$$

$\tau_{\mathrm{pl}}=\frac{\mathrm{r}_{m} \mathrm{r}_{g}^{2}}{6 b D_{p l} C_{i}}$

$\rho_{\mathrm{m}}$ being the molar density of $\mathrm{Fe}_{2} \mathrm{O}_{3}\left(32814 \mathrm{~mol} / \mathrm{m}^{3}\right), b$ the stoichiometric coefficient for solids in reactions (1), (2) or (3), and $r_{g}$ the characteristic length of the grains, calculated as:

$r_{g}=\frac{3}{10^{3} S_{B E T} \rho_{s}}=6.96 \cdot 10^{-7} \mathrm{~m}$

An Arrhenius temperature dependence of the kinetic constant and diffusivity was considered.

$$
\begin{aligned}
& k_{s}=k_{s, 0} e^{\frac{-E_{c h}}{R_{g} \cdot T}} \\
& D_{p l}=D_{p l, 0} e^{\frac{-E_{p l}}{R_{g} T}}
\end{aligned}
$$

Kinetic parameters were obtained by fitting predictions from the kinetic model to TGA conversion vs. time curves. The reaction order, $n$, with respect to each fuel gas $\left(\mathrm{H}_{2}, \mathrm{CO}\right.$ or $\mathrm{CH}_{4}$ ) was obtained from the calculus of $\tau_{\mathrm{ch}}$ by calculating the initial conversion rate as:

$$
\left.\frac{d X_{r e d}}{d t}\right|_{X_{r e d}=0}=\frac{1}{\tau_{c h}}
$$

Thereby, the following equation was deduced:

$$
\ln \left(\frac{\rho_{m} r_{g}}{b \tau_{c h}}\right)=\ln \left(k_{s}\right)+n \ln C_{i}
$$

From a plot of $\ln \left(\rho_{\mathrm{m}} r_{\mathrm{g}} / \mathrm{b} \tau_{\mathrm{ch}}\right)$ vs. $\ln \left(C_{i}\right)$ the values of the reaction order, $n$, can be obtained from the slope of the figure. Figure 7 shows this plot for $\mathrm{H}_{2}, \mathrm{CO}$ and $\mathrm{CH}_{4}$. The calculated reaction order for each reaction is shown in Table 3.

From the experiments carried out at different temperatures, values for the chemical reaction kinetic constant, $k_{s}$, and the diffusion coefficient, $D_{p l}$, as a function of the temperature were obtained. Relevant share of the diffusion in the product layer was only found for the 
reduction with $\mathrm{CO}$. The dependence on the temperature of $k_{s}$, and $D_{p l}$ was assumed to be Arrhenius type; see Figure 8. The values of the kinetic parameters finally obtained for the reduction of the oxygen carrier for $\mathrm{H}_{2}, \mathrm{CO}$ and $\mathrm{CH}_{4}$, are given in Table 3. Values for activation energies $81 \pm 7$ and $76 \pm 6 \mathrm{~kJ} / \mathrm{mol}$ were obtained for kinetic constant in the reduction with $\mathrm{H}_{2}$ and $\mathrm{CO}$, respectively, whereas a higher value $(257 \pm 14 \mathrm{~kJ} / \mathrm{mol})$ was obtained for reduction with $\mathrm{CH}_{4}$. High values for the activation energy in the reaction with methane were also obtained with similar types of iron ore. Luo et al. reported activation energies corresponding to 50 and $184 \mathrm{~kJ} / \mathrm{mol}$ for pure hematite and an iron ore (83 wt \% $\mathrm{Fe}_{2} \mathrm{O}_{3}$ ), respectively, in the 1123-1273 $\mathrm{K}$ temperature range [31]. In the study of another iron ore (98 wt $\% \mathrm{Fe}_{2} \mathrm{O}_{3}$ ), a value of $215 \mathrm{~kJ} / \mathrm{mol}$ for the transformation $\mathrm{Fe}_{2} \mathrm{O}_{3}$ to $\mathrm{Fe}_{3} \mathrm{O}_{4}$ was obtained in the 1073-1223 K temperature range [32]. However, lower values of activation energy were encountered for all the gases in studies with pure hematite [18-20, 42].

A different behavior was observed for the reduction with $\mathrm{CO}$, suggesting that chemical reaction was the limiting step at low conversion values but diffusion through the product layer was more relevant as solids were more converted. In addition, experimental curves showed a decrease in the reaction rate for temperatures higher than $1123 \mathrm{~K}$. As a result, the activation energy for effective diffusivity in the product layer shows a change from $139 \pm 5$ $\mathrm{kJ} / \mathrm{mol}$ at low temperatures to $-155 \pm 10 \mathrm{~kJ} / \mathrm{mol}$ at high temperatures. This negative activation energy denotes a decrease of the diffusivity in the product layer with the reacting temperature, likely linked to some effect of product layer sintering on the diffusion of species related with $\mathrm{CO}$.

The conversion-time curves predicted by the reaction model with the kinetic parameters obtained are shown in Figures 5 and 6 . As it can be seen the conversion curves are well predicted in all range of operating conditions studied for reduction of Tierga iron ore for all reducing gases. 


\subsection{Kinetic determination for the oxidation reaction of Tierga iron ore}

The CLC process is based on alternating reduction and oxidation reactions of the oxygen carrier. Thus, the reduced oxygen carrier from the fuel reactor is regenerated in the air reactor. Studies carried out by TGA showed that the oxidation rate was the same independently of the gas previously used for the reduction. To determine the kinetic parameters of the oxidation reaction several experiments at different temperatures (1073$1273 \mathrm{~K})$ and oxygen concentrations (5, 10, 15, and 21 vol\%) were carried out. Previously, the solid samples were reduced to $\mathrm{Fe}_{3} \mathrm{O}_{4}$ using 5 vol. $\% \mathrm{H}_{2}$ and 40 vol. $\% \mathrm{H}_{2} \mathrm{O}$.

\subsubsection{Effect of oxygen concentration}

To determine the reaction order of the oxidation reaction, several experiments were carried out at $1223 \mathrm{~K}$ as a function of the $\mathrm{O}_{2}$ concentration $(5,10,15$ and $21 \%)$. Figure 9 shows the conversion-time curves obtained. It can be observed that the reaction rate increases as the $\mathrm{O}_{2}$ concentration increases. Also, a high oxidation rate was observed which was barely affected by the solids conversion.

\subsubsection{Effect of temperature}

To determine the kinetic parameters of the oxidation reaction for this oxygen carrier, several experiments were carried out at different temperatures from 1073 to $1273 \mathrm{~K}$ with a constant oxygen concentration of $10 \mathrm{vol} \%$, and following the procedure described in the experimental section. Figure 10 shows the conversion vs. time curves obtained. On the contrary to the effect of the oxygen concentration, the reaction rate scarcely increased when the temperature was increased. That results are similar that found for other Fe-, Ni- or $\mathrm{Cu}-$ based oxygen carriers [3]. 


\subsubsection{Determination of the kinetic parameters for oxidation reaction}

Oxidation reaction was characterised by a quick step, with roughly constant reaction rate until complete conversion. This fact suggested that chemical reaction was the controlling step throughout all oxidation period. Thus, the dependence of the conversion with time can be expressed by the following equation:

$t=\tau_{c h}\left[1-\left(1-X_{o x}\right)^{1 / 3}\right]$

and $\tau_{c h}$ defined by equation (8), where $\rho_{\mathrm{m}}$ and $\mathrm{r}_{\mathrm{g}}$ are the molar density and the characteristic length of $\mathrm{Fe}_{3} \mathrm{O}_{4}$ grains, i.e. $\rho_{\mathrm{m}}=22330 \mathrm{~mol} / \mathrm{m}^{3}$ and $\left.\mathrm{r}_{\mathrm{g}}=6.81 \cdot 10^{-7} \mathrm{~m}\right)$. Parameter $b$ is the stoichiometric coefficient for solids in reaction $(b=4)$.

Therefore, the reaction order, $n$, of the oxidation reaction was obtained from the slope of the plot $\ln \left(\rho_{\mathrm{m}} r_{\mathrm{g}} / \mathrm{b} \tau_{\mathrm{ch}}\right)$ versus $\ln \left(\mathrm{C}_{\mathrm{O} 2}\right)$, as it is shown in Figure 8 . The reaction order is shown in Table 3.

By fitting the conversion curves obtained at different temperatures, the values of the chemical reaction constant, $k_{s}$, at each temperature was obtained. Assuming the Arrhenius dependence for $k_{s}$ with temperature, the values of the pre-exponential factor, and the activation energies were obtained; see Figure 8 . The values of the kinetic parameters finally obtained for the oxidation of Tierga iron ore are given in Table 3. Low value for the activation energy was obtained $(18.4 \pm 0.5 \mathrm{~kJ} / \mathrm{mol})$.

The conversion-time curves predicted for oxidation by the reaction model in the particle with the kinetic parameters obtained are shown in Figures 9 and 10. It can be observed that the theoretical curves predict adequately the experimental results. 


\section{Comparison between Fe-based oxygen carriers}

During the development of new oxygen carriers, it becomes necessary to find ways to compare their performance in order to select the most promising for the CLC process. One of the first aspects to be compared is their reactivity. In order to perform a reactivity comparison, the rate index parameter has been widely used in the screening process of different oxygen carriers due to its simplicity $[36,43,44]$. The rate index is a normalized rate at a reference partial pressure $p_{\text {ref }}$ of 0.15 atm for reduction and 0.10 atm for oxidation, expressed in $\% / \mathrm{min}$ by equation (16).

rate index $=100 \cdot 60 \cdot\left(\left|\frac{d \omega}{d t}\right|\right)_{\text {norm }}=100 \cdot 60 \cdot R_{O C} \cdot \frac{p_{r e f}}{p_{T G A}} \cdot\left(\frac{d X_{i}}{d t}\right)$

where $\omega$ is the mass-based conversion and $X_{i}$ is the conversion for reduction or oxidation.

For the calculation of the rate index is not necessary to know the kinetic parameters of the reaction of the oxygen carrier with different combustion gases. Only reactivity tests in a TGA under defined conditions are needed. However, while it can be used to quickly discard some of the oxygen carriers tested, it is not accurate in the calculation of their real reactivity because the variation of the reaction rate with the reacting gas concentration is not considered [8]. However, when kinetics is available, it is possible to use the value of the solids inventory in fuel and air reactors as a good value for comparison. Thus, if the kinetic parameters have been determined, the reaction order $(n)$, and the gas expansion $\left(\varepsilon_{g}\right)$ are known so that the average concentration can be more accurately calculated in each case. Therefore, a better comparison between oxygen carriers can be done and different conclusions can be obtained with respect to those reached using the rate index.

A simplified model was developed to obtain an initial estimation of the minimum solids inventory to reach full conversion of fuel gas [8]. Ideally, the minimum solids inventory is calculated for values of $\Delta \mathrm{X} \rightarrow 0$, where the reaction is only controlled by chemical reaction. 
Thus, the chemical reaction control was assumed to be the controlling mechanism to calculate the reaction rates. Moreover, this simplified model assumes perfect mixing of solids and the shrinking core model for the solid reaction. Equations (17) and (18) are used in the calculation of the mass of solids in the fuel and air reactors per $\mathrm{MW}_{\text {th }}$ of fuel for gaseous fuels [8]:

$m_{O C}=\eta_{C} \frac{2 d M_{O}}{R_{O C} \cdot \Delta H_{C}^{0}} \frac{\tau}{\Phi}$

and solid fuels [45]:

$$
m_{O C}=\eta_{C} \frac{10^{3} m_{O}}{R_{O C} \cdot \operatorname{LHV}} \frac{\tau}{\Phi}
$$

where $m_{O}$ is the mass of oxygen required per $\mathrm{kg}$ of solid fuel to fully convert the solid fuel to $\mathrm{CO}_{2}$ and $\mathrm{H}_{2} \mathrm{O}$ and $\Phi$ is the characteristic reactivity as it has been defined before [8]. Coal was considered as solid fuel in order to compare different oxygen carriers. A typical composition was used consisting in $70 \%$ carbon, $5 \%$ hydrogen and $10 \%$ oxygen, corresponding to $m_{O}=2.2$ $\mathrm{kg} \mathrm{O} / \mathrm{kg}$ coal. The LHV was assumed to be $25000 \mathrm{~kJ} / \mathrm{kg}$.

In both equations, it is necessary to calculate the average reactivity represented by the $\tau$ value $\left(\left.\tau\right|_{X_{i}=0}\right)_{a v}$. This value is calculated at the average gas concentration in the reactor $\left(\bar{C}_{g}\right)$ when the conversion of the oxygen carrier is zero $\left(X_{i}=0\right)$. The equation to calculate the average concentration for $\mathrm{H}_{2}, \mathrm{CO}$ and $\mathrm{CH}_{4}$, considering the reaction order $n=1$, is showed next:

$$
\bar{C}_{g}=\frac{\Delta X_{g} C_{i, 0}}{\varepsilon_{g}\left(X_{g, \text { in }}-X_{g, \text { out }}\right)+\left(1+\varepsilon_{g}\right) \ln \left[\frac{1-X_{g, \text { in }}}{1-X_{g, \text { out }}}\right]}
$$

being $\varepsilon_{g}$ the gas expansion as a consequence of the reaction, calculated by: 


$$
\varepsilon_{g}=\frac{V_{g, X_{g}=1}-V_{g, X_{g}=0}}{V_{g, X_{g}=0}}
$$

The value of $\varepsilon_{g}$ was 2 for the reduction reaction with $\mathrm{CH}_{4}$ and 0 for $\mathrm{H}_{2}$ and $\mathrm{CO}$. Moreover, the average concentration considers a gas conversion of $X_{g, \text { out }}=99.9 \%$ in the fuel reactor. For coal, only $\mathrm{H}_{2}$ and $\mathrm{CO}$ coming from coal gasification were considered. To facilitate the comparison with ilmenite $\mathrm{CO}$ was assimilated to $\mathrm{H}_{2}$ and an initial concentration of $5 \% \mathrm{H}_{2}$ was assumed [45]. In this respect, additional experiments were performed with the Tierga iron ore and mixtures $\mathrm{CO}+\mathrm{H}_{2}$ as reacting gas in order to analyse the reactivity of the carrier in the presence of both gases. Figure 11 shows the conversion vs. time curves corresponding to experiments with different $\mathrm{H}_{2}$ and $\mathrm{CO}$ concentrations. In Figure 11 (A), $\mathrm{H}_{2}$ concentration was higher than $\mathrm{CO}$ concentration. In Figure 11 (B) both gases were present at the same concentration and in Figure 11 (C) $\mathrm{H}_{2}$ concentration was lower than that corresponding to $\mathrm{CO}$. Each graph shows four curves: those corresponding to the reacting gases alone and those corresponding to the reaction with the mixture $\mathrm{CO}+\mathrm{H}_{2}$, both determined experimentally and calculated from the sum of that for each reacting gas. In any of the three graphs shown in Figure 11, the experiment with the mixture $\mathrm{CO}+\mathrm{H}_{2}$ presented the decrease in the slope of the conversion vs. time curve previously observed in the experiments with only $\mathrm{CO}$, indicating that the influence of the diffusion through the product layer is not significant in the experiments with $\mathrm{CO}+\mathrm{H}_{2}$ mixtures as it was in the $\mathrm{CO}$ experiments. Another result that should be highlighted is the fact that the experimental curve for the mixture $\mathrm{CO}+\mathrm{H}_{2}$ is similar in all the cases to that calculated as the sum of the curves for $\mathrm{CO}$ and $\mathrm{H}_{2}$. This has been previously reported before for Fe-based materials [27].

Table 4 presents the rate index values and minimum solids inventories obtained at different temperatures with $\mathrm{H}_{2}, \mathrm{CO}, \mathrm{CH}_{4}$ and coal as fuels when Tierga ore is used as oxygen carrier. These values are compared to those estimated for ilmenite under similar conditions [28]. The 
rate index compares the reactivity in a determined condition: $1223 \mathrm{~K}$ and $15 \mathrm{vol} \%$ of fuel gas in usually taken as reference condition. But the reaction rate varies in a different way with temperature and gas concentration depending on the reaction order and activation energy of the reaction. To consider these parameters the solids inventory are calculated. Note that the solids inventory values correspond to the minimum solids inventory required from a kinetic point of view; but the inventories needed in a real CLC system would be higher due to an imperfect contact between gas and solids in a reactor. Here the values of solids inventory are only affected by the different reaction kinetics and oxygen transport capacity of the materials, namely $R_{O C}$ is $3.3 \%$ for activated ilmenite [28] and $2.8 \%$ for the Tierga iron ore here used, and they are only used for comparison purposes between oxygen carriers. Regarding the reduction reactions, lower minimum solid inventories were obtained for both oxygen carriers with the syngas components $\left(\mathrm{H}_{2}\right.$ and $\left.\mathrm{CO}\right)$ than with methane. Moreover, the solid inventories with Tierga ore were even lower than those corresponding to ilmenite, except in the case of methane as fuel. Nevertheless, temperature strongly affects the reactivity of Tierga ore with methane so that at the highest temperature $(1273 \mathrm{~K})$, the solid inventories needed for complete methane combustion are comparable $\left(167 \mathrm{~kg} / \mathrm{MW}_{\text {th }}\right.$ for ilmenite and $250 \mathrm{~kg} / \mathrm{MW}_{\text {th }}$ for Tierga ore). Compared to the fuel reactor, lower solid inventories were found for both oxygen carriers in the air reactor due to the higher reactivity of both materials for the oxidation reaction compared to the reduction reactions. In both cases, there is little influence of temperature on the values of solid inventories. However, the solid inventories in the air reactor were higher for Tierga ore when compared to ilmenite, approximately twice the values for ilmenite.

From the analysis in Table 4 it can be concluded that Tierga ore can be an interesting alternative to ilmenite in solid fuel combustion due to its higher reactivity to the main 
gasification gases $\left(\mathrm{H}_{2}\right.$ and $\left.\mathrm{CO}\right)$. Nevertheless, in order to reach adequate methane conversion high temperatures $(>1250 \mathrm{~K})$ should be used in the combustion of coal.

\section{Conclusions}

TGA experiments were carried out to obtain reaction rates of relevant redox processes involving Tierga iron ore particles in CLC with coal. Reaction kinetic models were used to determine kinetic parameters for Tierga ore reduction with $\mathrm{H}_{2}, \mathrm{CO}$ and $\mathrm{CH}_{4}$, as well as oxidation with $\mathrm{O}_{2}$.

For an adequate description of the reaction of Tierga ore with $\mathrm{H}_{2}, \mathrm{CO}, \mathrm{CH}_{4}$ and $\mathrm{O}_{2}$ it was assumed that Tierga ore particles were composed by small grains of reactive solid, each one with spherical shape. Every grain was reacting following the shrinking core model, and both chemical reaction control and diffusion of reacting compounds through the product layer were considered for reduction reactions. For oxidation, only chemical reaction control was considered.

High reaction rates were found for reduction with $\mathrm{H}_{2}$ and oxidation reactions. Lower reaction rates were observed for reduction with $\mathrm{CO}$ and $\mathrm{CH}_{4}$. Reaction order values close to 1 were obtained. An increase of temperature increased the reaction rate, although this increase was very low for oxidation. The relevance of the diffusion through the product layer was only relevant for the reduction with $\mathrm{CO}$.

We can conclude that with the kinetic models developed in this work, it was possible to predict the reduction and oxidation reaction rates at different environmental conditions (gas concentration and temperature) in a broad range of operation conditions suitable for the use of Tierga iron ore in $i G$-CLC with coal. Moreover, the kinetic parameters determined for Tierga ore allowed to estimate the minimum solid inventory required for the combustion of gaseous fuels $\left(\mathrm{H}_{2}, \mathrm{CO}, \mathrm{CH}_{4}\right)$ and coal and compared them to those previously determined for 
ilmenite. According to this, Tierga ore can replace ilmenite in solid fuel combustion due to its higher reactivity to the main gasification gases from coal $\left(\mathrm{H}_{2}\right.$ and $\left.\mathrm{CO}\right)$. In order to reach adequate methane conversion high temperatures $(>1250 \mathrm{~K})$ should be used in the combustion of coal.

\section{Acknowledgments}

This work was supported by the Spanish Ministry of Economy and Competitiveness (projects ENE2014-56857-R, ENE2016-77982-R), by the European Regional Development Fund (ERDF), the EU project ACCLAIM (RFCP-CT-2012-00006). T. Mendiara thanks for the

“Ramón y Cajal”" post-doctoral contract awarded by the Spanish Ministry of Economy and Competitiveness. The authors also thank PROMINDSA for providing the iron ore used in this work. 


\section{Bibliography}

[1] A. Lyngfelt, B. Leckner, T. Mattisson, A fluidized-bed combustion process with inherent $\mathrm{CO}_{2}$ separation; Application of chemical-looping combustion, Chem. Eng. Sci. 56 (2001) 3101-3113.

[2] J. Adánez, A. Abad, T. Mendiara, P. Gayán, L.F. de Diego, F. García-Labiano, Chemical looping combustion of solid fuels, Prog. Energy Combust. Sci. 65 (2018) 6-66.

[3] J. Adanez, A. Abad, F. Garcia-Labiano, P. Gayan, L.F. De Diego, Progress in chemicallooping combustion and reforming technologies, Prog. Energy Combust. Sci. 38 (2012) 215282.

[4] T. Mendiara, L.F. De Diego, F. García-Labiano, P. Gayán, A. Abad, J. Adánez, On the use of a highly reactive iron ore in Chemical Looping Combustion of different coals, Fuel 126 (2014) 239-249.

[5] J. Adánez, P. Gayán, I. Adánez-Rubio, A. Cuadrat, T. Mendiara, A. Abad, F. GarcíaLabiano, L.F. De Diego, Use of Chemical-Looping processes for coal combustion with $\mathrm{CO}_{2}$ capture, Enrgy. Proced. 37 (2013) 540-549.

[6] T. Mendiara, A. Pérez-Astray, M.T. Izquierdo, A. Abad, L.F. de Diego, F. GarcíaLabiano, P. Gayán, J. Adánez, Chemical Looping Combustion of different types of biomass in a $0.5 \mathrm{~kW}_{\text {th }}$ unit, Fuel 211 (2018) 868-875.

[7] C. Linderholm, M. Schmitz, M. Källén, A. Lyngfelt, Use of iron ore as oxygen carrier in a $100 \mathrm{~kW}$ chemical-looping combustor for solid fuels, $22^{\text {nd }}$ International Conference on Fluidized Bed ConversionTurku, (Finland). , 2015.

[8] A. Abad, J. Adánez, F. García-Labiano, L.F. de Diego, P. Gayán, J. Celaya, Mapping of the range of operational conditions for $\mathrm{Cu}-, \mathrm{Fe}-$, and Ni-based oxygen carriers in chemicallooping combustion, Chem. Eng. Sci. 62 (2007) 533-549.

[9] A. Abad, P. Gayán, L.F. de Diego, F. García-Labiano, J. Adánez, Fuel reactor modelling in chemical-looping combustion of coal: 1. model formulation, Chem. Eng. Sci. 87 (2013) 277-293.

[10] F. García-Labiano, L.F. de Diego, P. Gayán, A. Abad, J. Adánez, Fuel reactor modelling in chemical-looping combustion of coal: 2. simulation and optimization, Chem. Eng. Sci. 87 (2013) 173-182.

[11] P. Gayán, A. Abad, L.F. de Diego, F. García-Labiano, J. Adánez, Assessment of technological solutions for improving chemical looping combustion of solid fuels with $\mathrm{CO}_{2}$ capture, Chem. Eng. J. 233 (2013) 56-69.

[12] A. Abad, J. Adánez, L.F. de Diego, P. Gayán, F. García-Labiano, A. Lyngfelt, Fuel reactor model validation: Assessment of the key parameters affecting the chemical-looping combustion of coal, Int. J. Greenh. Gas Con. 19 (2013) 541-551.

[13] T.A. Brown, J.S. Dennis, S.A. Scott, J.F. Davidson, A.N. Hayhurst, Gasification and chemical-looping combustion of a lignite char in a fluidized bed of iron oxide, Energy Fuels 24 (2010) 3034-3048.

[14] M. Kramp, A. Thon, E.U. Hartge, S. Heinrich, J. Werther, Carbon Stripping - A Critical Process Step in Chemical Looping Combustion of Solid Fuels, Chem. Eng. Technol. 35 (2012) 497-507. 
[15] J.M. Parker, CFD model for the simulation of chemical looping combustion, Powder Technol. 265 (2014) 47-53.

[16] P. Ohlemüller, F. Alobaid, A. Gunnarsson, J. Ströhle, B. Epple, Development of a process model for coal chemical looping combustion and validation against $100 \mathrm{~kW}_{\text {th }}$ tests, Appl. Energ. 157 (2015) 433-448.

[17] P. Ohlemüller, F. Alobaid, A. Abad, J. Adanez, J. Ströhle, B. Epple, Development and validation of a $1 \mathrm{D}$ process model with autothermal operation of a $1 \mathrm{MW}_{\text {th }}$ chemical looping pilot plant, Int. J. Greenh. Gas Con. 73 (2018) 29-41.

[18] E.R. Monazam, R.W. Breault, R. Siriwardane, G. Richards, S. Carpenter, Kinetics of the reduction of hematite $\left(\mathrm{Fe}_{2} \mathrm{O}_{3}\right)$ by methane $\left(\mathrm{CH}_{4}\right)$ during chemical looping combustion: A global mechanism, Chem. Eng. J. 232 (2013) 478-487.

[19] E.R. Monazam, R.W. Breault, R. Siriwardane, Kinetics of magnetite $\left(\mathrm{Fe}_{3} \mathrm{O}_{4}\right)$ oxidation to hematite $\left(\mathrm{Fe}_{2} \mathrm{O}_{3}\right)$ in air for chemical looping combustion, Ind. Eng. Chem. Res. 53 (2014) $13320-13328$.

[20] E.R. Monazam, R.W. Breault, R. Siriwardane, Kinetics of hematite to wüstite by hydrogen for chemical looping combustion, Energy Fuels 28 (2014) 5406-5414.

[21] M. Su, J. Ma, X. Tian, H. Zhao, Reduction kinetics of hematite as oxygen carrier in chemical looping combustion, Fuel Process. Technol. 155 (2017) 160-167.

[22] X. Hua, W. Wang, F. Wang, Performance and kinetics of iron-based oxygen carriers reduced by carbon monoxide for chemical looping combustion, Frontiers of Environmental Science and Engineering 9 (2015) 1130-1138.

[23] E. Ksepko, M. Sciazko, P. Babinski, Studies on the redox reaction kinetics of $\mathrm{Fe}_{2} \mathrm{O}_{3}$ $\mathrm{CuO} / \mathrm{Al}_{2} \mathrm{O}_{3}$ and $\mathrm{Fe}_{2} \mathrm{O}_{3} / \mathrm{TiO}_{2}$ oxygen carriers, Appl. Energ. 115 (2014) 374-383.

[24] Y. Zhang, E. Doroodchi, B. Moghtaderi, Reduction kinetics of $\mathrm{Fe}_{2} \mathrm{O}_{3} / \mathrm{Al}_{2} \mathrm{O}_{3}$ by ultralow concentration methane under conditions pertinent to chemical looping combustion, Energy Fuels 29 (2015) 337-345.

[25] A. Cabello, A. Abad, F. García-Labiano, P. Gayán, L.F. de Diego, J. Adánez, Kinetic determination of a highly reactive impregnated $\mathrm{Fe}_{2} \mathrm{O}_{3} / \mathrm{Al}_{2} \mathrm{O}_{3}$ oxygen carrier for use in gasfueled Chemical Looping Combustion, Chem. Eng. J. 258 (2014) 265-280.

[26] D. Mei, H. Zhao, S. Yan, Kinetics model for the reduction of $\mathrm{Fe}_{2} \mathrm{O}_{3} / \mathrm{Al}_{2} \mathrm{O}_{3}$ by $\mathrm{CO}$ in Chemical Looping Combustion, Chem. Eng. Process. 124 (2018) 137-146.

[27] A. Abad, F. García-Labiano, L.F. de Diego, P. Gayán, J. Adánez, Reduction kinetics of $\mathrm{Cu}-$, Ni-, and Fe-based oxygen carriers using syngas $\left(\mathrm{CO}+\mathrm{H}_{2}\right)$ for chemical-looping combustion, Energy Fuels 21 (2007) 1843-1853.

[28] A. Abad, J. Adánez, A. Cuadrat, F. García-Labiano, P. Gayán, L.F. de Diego, Kinetics of redox reactions of ilmenite for chemical-looping combustion, Chem. Eng. Sci. 66 (2011) 689702.

[29] P. Perreault, H. Stainton, M. Yazdanpanah, G.S. Patience, Kinetic modelling of ilmenite reduction by $\mathrm{CO}, \mathrm{H}_{2}$ and $\mathrm{CH}_{4}, 2^{\text {nd }}$ International Conference on Chemical LoopingDarmstadt (Germany), 2012.

[30] G.L. Schwebel, S. Sundqvist, W. Krumm, H. Leion, Apparent kinetics derived from fluidized bed experiments for Norwegian ilmenite as oxygen carrier, Journal of Environmental Chemical Engineering 2 (2014) 1131-1141. 
[31] M. Luo, S. Wang, L. Wang, M. Lv, Reduction kinetics of iron-based oxygen carriers using methane for chemical-looping combustion, J. Power Sources 270 (2014) 434-440.

[32] S. Nasr, K.P. Plucknett, Kinetics of iron ore reduction by methane for chemical looping combustion, Energy Fuels 28 (2014) 1387-1395.

[33] H. Cao, X.L. Liu, Z. Wen, G.F. Lou, Reaction characteristics of sintering ore used as an oxygen carrier in chemical looping combustion, Gongcheng Kexue Xuebao/Chinese Journal of Engineering 37 (2015) 422-428.

[34] M.H. Jeong, D.H. Lee, J.W. Bae, Reduction and oxidation kinetics of different phases of iron oxides, Int. J. Hydrogen Energ. 40 (2015) 2613-2620.

[35] E. Ksepko, P. Babinski, A. Evdou, L. Nalbandian, Studies on the redox reaction kinetics of selected, naturally occurring oxygen carrier, J. Therm. Anal. Calorim. 124 (2016) 137-150.

[36] T. Mendiara, R. Pérez, A. Abad, L.F. De Diego, F. García-Labiano, P. Gayán, J. Adánez, Low-cost Fe-based oxygen carrier materials for the $i \mathrm{G}-\mathrm{CLC}$ process with coal. 1, Ind. Eng. Chem. Res. 51 (2012) 16216-16229.

[37] J. Adánez, L.F. De Diego, F. García-Labiano, P. Gayán, A. Abad, J.M. Palacios, Selection of oxygen carriers for chemical-looping combustion, Energy Fuels 18 (2004) 371377.

[38] W. Hu, F. Donat, S.A. Scott, J.S. Dennis, Kinetics of oxygen uncoupling of a copper based oxygen carrier, Appl. Energ. 161 (2016) 92-100.

[39] F. García-Labiano, L.F. De Diego, J. Adánez, A. Abad, P. Gayán, Temperature variations in the oxygen carrier particles during their reduction and oxidation in a chemicallooping combustion system, Chem. Eng. Sci. 60 (2005) 851-862.

[40] J. Szekely, J. Evans, A structural model for gas-solid reactions with a moving boundary, Chem. Eng. Sci. 25 (1970) 1091.

[41] O. Levenspiel, Chemical Reaction Engineering, New York, 1981.

[42] E.R. Monazam, R.W. Breault, R. Siriwardane, Reduction of hematite $\left(\mathrm{Fe}_{2} \mathrm{O}_{3}\right)$ to wüstite (FeO) by carbon monoxide (CO) for chemical looping combustion, Chem. Eng. J. 242 (2014) 204-210.

[43] R. Pérez-Vega, A. Abad, F. García-Labiano, P. Gayán, L.F. de Diego, M.T. Izquierdo, J. Adánez, Chemical Looping Combustion of gaseous and solid fuels with manganese-iron mixed oxide as oxygen carrier, Energy Convers. Manage. 159 (2018) 221-231.

[44] M. Arjmand, H. Leion, T. Mattisson, A. Lyngfelt, Investigation of different manganese ores as oxygen carriers in chemical-looping combustion (CLC) for solid fuels, Appl. Energ. 113 (2014) 1883-1894.

[45] J. Adánez, A. Cuadrat, A. Abad, P. Gayán, L.F. De Diego, F. García-Labiano, Ilmenite activation during consecutive redox cycles in chemical-looping combustion, Energy Fuels 24 (2010) 1402-1413. 


\section{Nomenclature}

$b \quad$ Stoichiometric coefficient for reaction of solid (mol of solid / mol of gas)

$C_{i} \quad$ Concentration of gas $i\left(\mathrm{~mol} \cdot \mathrm{m}^{3}\right)$

$\bar{C}_{g} \quad$ Average gas concentration $\left(\mathrm{mol} \cdot \mathrm{m}^{3}\right)$

$d$

Stoichiometric factor in the fuel combustion reaction with oxygen (mol of $\mathrm{O}_{2} /$ mol of fuel)

$D_{p l} \quad$ Effective diffusivity in the product layer $\left(\mathrm{m}^{2} \mathrm{~s}^{-1}\right)$.

$D_{p l, 0} \quad$ Pre-exponential factor for effective diffusivity $\left(\mathrm{m}^{2} \mathrm{~s}^{-1}\right)$

$\Delta H_{c}{ }^{0} \quad$ Standard combustion heat of the gas fuel $\left(\mathrm{kJ} \cdot \mathrm{mol}^{-1}\right)$

$E_{c h}$

Activation energy of the chemical reaction rate constant $\left(\mathrm{J} \mathrm{mol}^{-1}\right)$

$E_{p l}$

$k_{s}$

Activation energy for effective diffusivity in the product layer $\left(\mathrm{J} \mathrm{mol}^{-1}\right)$

$k_{s, 0}$

Chemical reaction kinetic constant $\left(\mathrm{mol}^{1-\mathrm{n}} \mathrm{m}^{3 \mathrm{n}-2} \mathrm{~s}^{-1}\right)$

Pre-exponential factor for chemical kinetic constant $\left(\mathrm{mol}^{1-\mathrm{n}} \mathrm{m}^{3 \mathrm{n}-2} \mathrm{~s}^{-1}\right)$.

$K_{e q}$

Equilibrium constant (-)

$m$

Mass of the sample at each time in TGA $(\mathrm{kg})$

$m_{\mathrm{OC}}$

Mass of oxygen carrier in fuel/air reactors per $\mathrm{MW}_{\text {th }}$ of fuel $(\mathrm{kg} / \mathrm{MW})$

$m_{\mathrm{O}}$

Mass of oxygen to fully convert the solid fuel to $\mathrm{CO}_{2}$ and $\mathrm{H}_{2} \mathrm{O}(\mathrm{kg} \mathrm{O} / \mathrm{kg}$ fuel)

$m_{\mathrm{ox}}$

$m_{\text {red }}$

$M_{\mathrm{O}}$

$n$

Mass of the oxygen carrier sample fully oxidized $(\mathrm{kg})$

$r_{g}$

$R_{g}$

Mass of the oxygen carrier sample fully reduced $(\mathrm{kg})$

Molecular weight of oxygen $\left(16 \mathrm{~g} \mathrm{~mol}^{-1}\right)$

Reaction order (-)

Characteristic length of the grain $(\mathrm{m})$

$R_{\mathrm{OC}}$

Gas constant $\left(8.314 \mathrm{~J} \cdot \mathrm{mol}^{-1} \cdot \mathrm{K}^{-1}\right)$

$S_{B E T}$

Oxygen transport capacity (-)

$t \quad$ Time (s)

$T \quad$ Temperature (K)

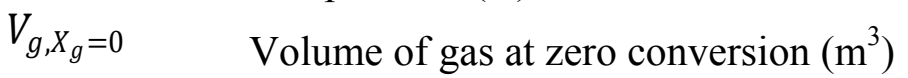

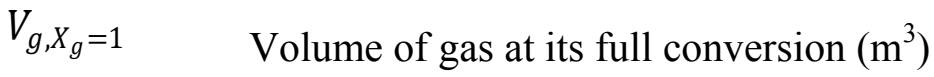

$X_{g} \quad$ Gaseous fuel conversion (-)

$X_{\text {red }} \quad$ Oxygen carrier reduction conversion (-)

$X_{o x} \quad$ Oxygen carrier oxidation conversion (-)

Symbols

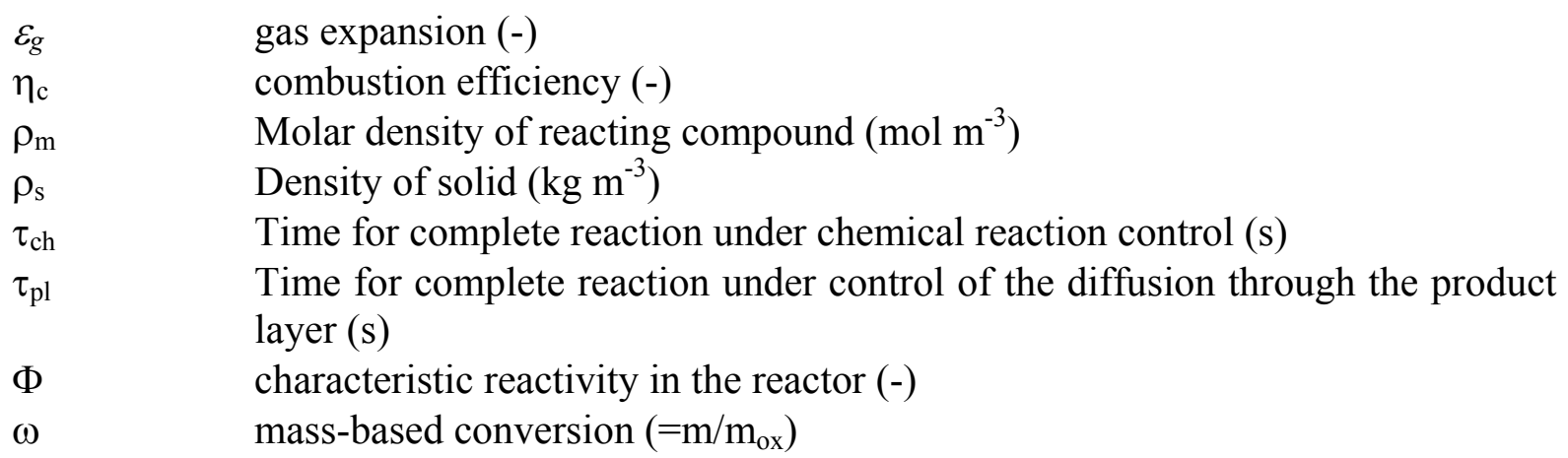


Acronyms

$\mathrm{LHV}=$ lower heating value of the solid fuel $(\mathrm{kJ} / \mathrm{kg})$ 


\section{List of Figure Captions}

Figure 1. Scheme of the $i \mathrm{G}-\mathrm{CLC}$ process

Figure 2. CI thermobalance

Figure 3. Conversion in the reducing period versus time from TGA experiments at $1223 \mathrm{~K}$ and $15 \mathrm{vol} \% \mathrm{H}_{2}$ for Tierga iron ore as received $(-)$, calcined $(\cdots \cdots)$ and activated $(--)$. Arrows show the variation on reactivity when particles were calcined and then exposed to redox cycles

Figure 4. Weight-loss curves obtained during the reduction of Tierga iron ore using (a) several $\mathrm{H}_{2} \mathrm{O}$ fraction in gas with 5 vol $\% \mathrm{H}_{2}$ or (b) several $\mathrm{CO}_{2}$ fraction in gas with $5 \mathrm{vol} \%$ CO. $\mathrm{N}_{2}$ to balance

Figure 5. Effect of fuel gas concentration on the reduction reaction of Tierga iron ore for (a) $\mathrm{H}_{2}+20$ vol $\% \mathrm{H}_{2} \mathrm{O}$, (b) $\mathrm{CO}+20$ vol $\% \mathrm{CO}_{2}$ and (c) $\mathrm{CH}_{4}+20$ vol $\% \mathrm{H}_{2} \mathrm{O} . T=1223 \mathrm{~K}$. Continuous lines: experimental curves; dashed lines: model predictions

Figure 6. Effect of reacting temperature on the reduction reaction of Tierga iron ore for (a) 5 vol $\% \mathrm{H}_{2}+20$ vol $\% \mathrm{H}_{2} \mathrm{O}$, (b) 5 vol $\% \mathrm{CO}+20$ vol $\% \mathrm{CO}_{2}$ and (c) 5 vol $\% \mathrm{CH}_{4}+20$ vol $\% \mathrm{H}_{2} \mathrm{O}$. Continuous lines: experimental curves; dashed lines: model predictions

Figure 7. Plot to obtain the reaction order with respect to $\mathrm{H}_{2}, \mathrm{CO}, \mathrm{CH}_{4}$ and $\mathrm{O}_{2}$ for Tierga iron ore particles. The figure shows the values in a confidence interval $95 \%$ considering five redox cycles

Figure 8. Arrhenius plot for the reaction of $\mathrm{H}_{2}, \mathrm{CO}, \mathrm{CH}_{4}$ and $\mathrm{O}_{2}$ with Tierga iron ore for (a) the kinetic constant, $k_{s}$ and (b) the diffusion coefficient, $D_{p l}$ for CO. The figure shows the values in a confidence interval 95\% considering five redox cycles.

Figure 9. Effect of $\mathrm{O}_{2}$ concentration on the oxidation reaction for Tierga iron ore. $\mathrm{T}=1223$ K. Continuous lines: experimental curves; dashed lines: model predictions 
Figure 10. Effect of temperature on the oxidation reaction for Tierga iron ore. $10 \mathrm{vol} \% \mathrm{O}_{2}$. Continuous lines: experimental curves; dashed lines: model predictions.

Figure 11. Conversion vs time curves for $\mathrm{H}_{2}$ and $\mathrm{CO}$ mixtures with Tierga iron ore at $\mathrm{T}=1223$ K. Conditions: (a) $10 \% \mathrm{CO} 20 \% \mathrm{H}_{2} 35 \% \mathrm{H}_{2} \mathrm{O} 11 \% \mathrm{CO}_{2} 24 \% \mathrm{~N}_{2}$ (b) $15 \% \mathrm{CO} 15 \%$ $\mathrm{H}_{2} 30 \% \mathrm{H}_{2} \mathrm{O} 18 \% \mathrm{CO}_{2} 22 \% \mathrm{~N}_{2}$ (c) $30 \% \mathrm{CO} 10 \% \mathrm{H}_{2} 20 \% \mathrm{H}_{2} \mathrm{O} 35 \% \mathrm{CO}_{2} 5 \% \mathrm{~N}_{2}$ 


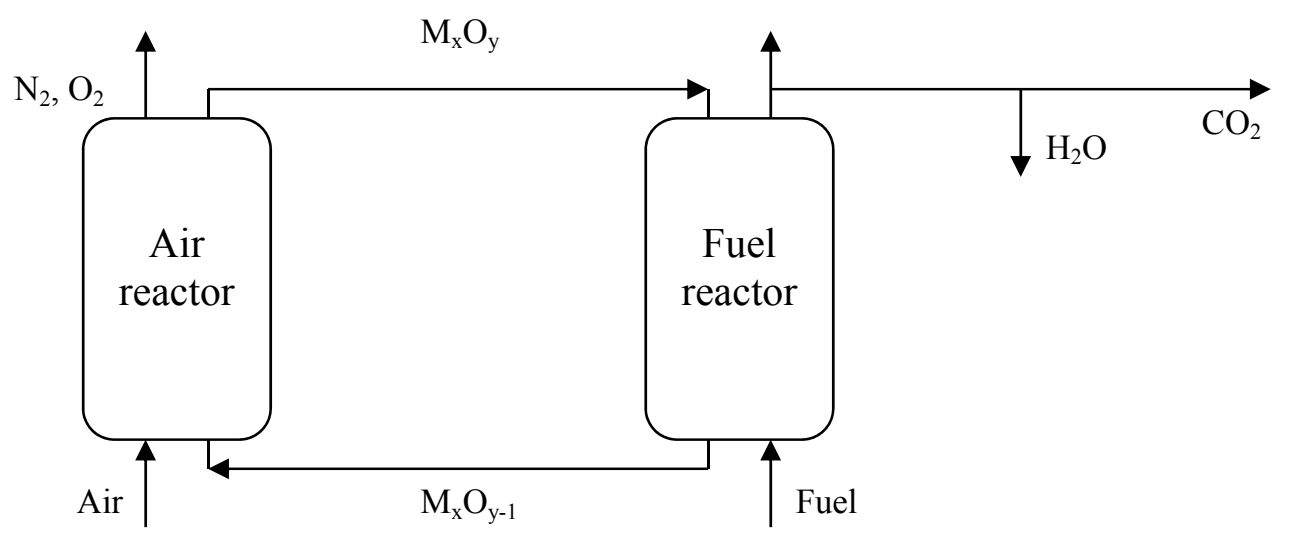

Figure 1. Scheme of the $i \mathrm{G}-\mathrm{CLC}$ process 


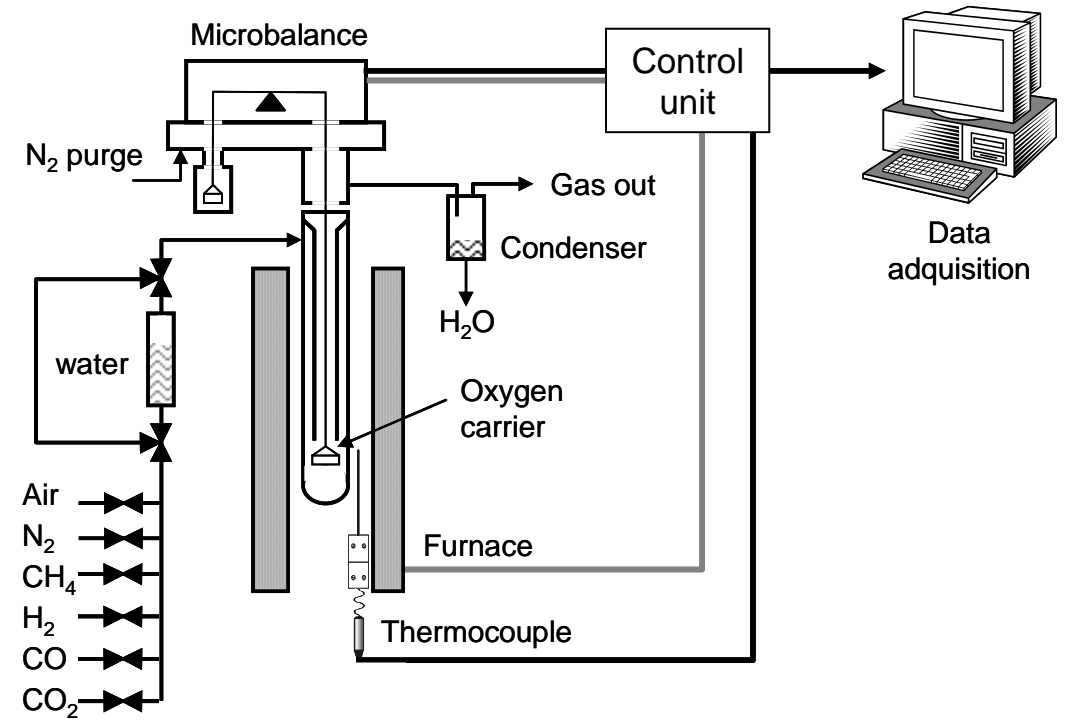

Figure 2. CI thermobalance 


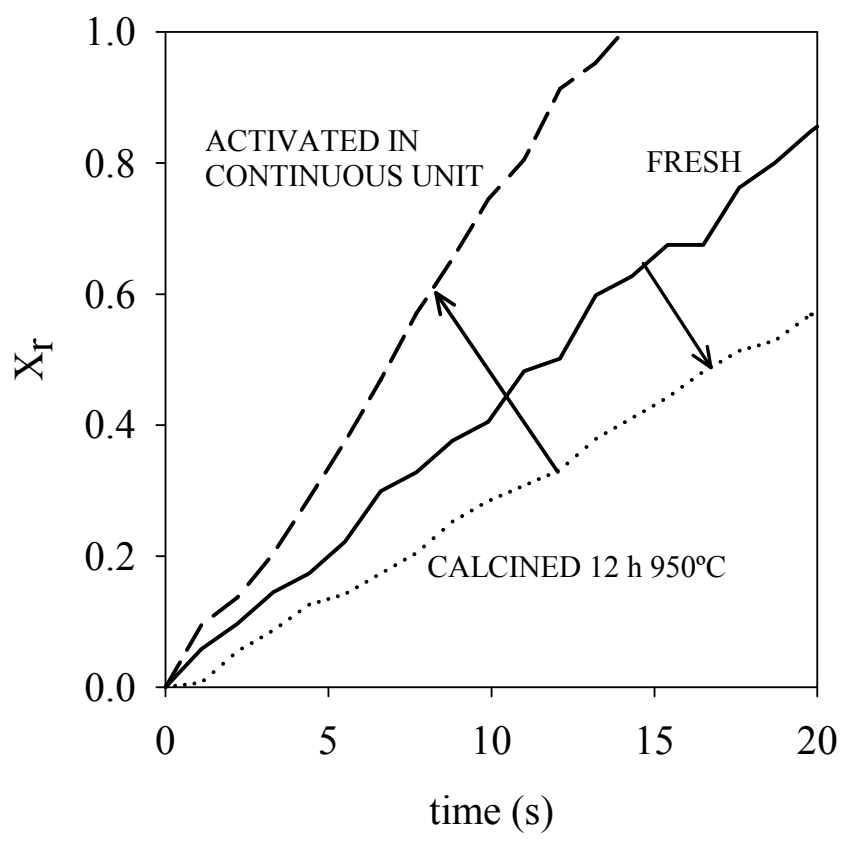

Figure 3. Conversion in the reducing period versus time from TGA experiments at $1223 \mathrm{~K}$ and $15 \mathrm{vol} \% \mathrm{H}_{2}$ for Tierga iron ore as received (-), calcined $(\cdots \cdots)$ and activated $(--)$. Arrows show the variation on reactivity when particles were calcined and then exposed to redox cycles 

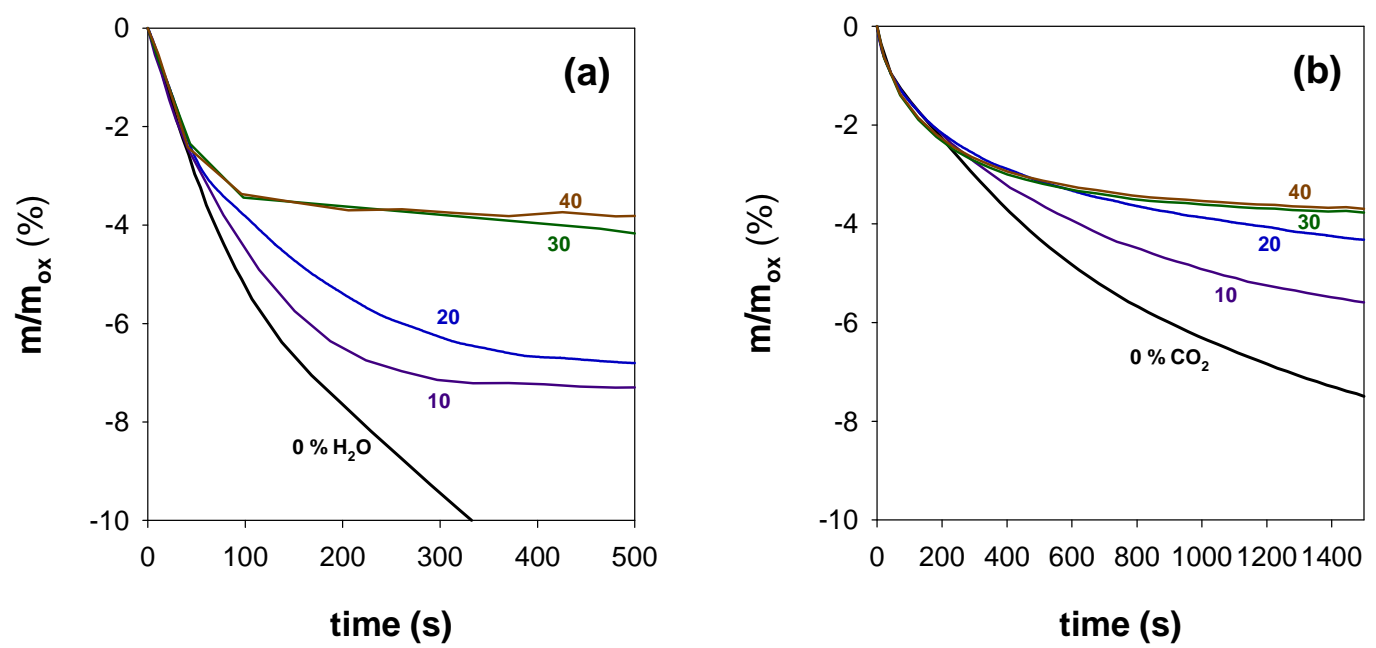

Figure 4. Weight-loss curves obtained during the reduction of Tierga iron ore using (a) several $\mathrm{H}_{2} \mathrm{O}$ fraction in gas with $5 \mathrm{vol} \% \mathrm{H}_{2}$ or (b) several $\mathrm{CO}_{2}$ fraction in gas with $5 \mathrm{vol} \%$ CO. $\mathrm{N}_{2}$ to balance 

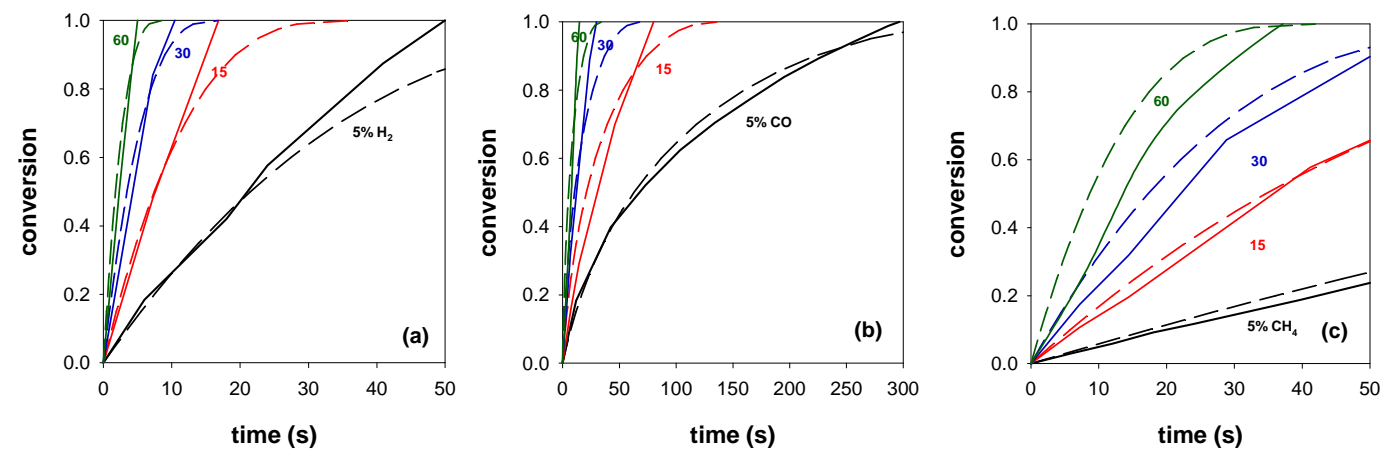

Figure 5. Effect of fuel gas concentration on the reduction reaction of Tierga iron ore for (a)

$\mathrm{H}_{2}+20$ vol\% $\mathrm{H}_{2} \mathrm{O}$, (b) $\mathrm{CO}+20$ vol\% $\mathrm{CO}_{2}$ and (c) $\mathrm{CH}_{4}+20$ vol\% $\mathrm{H}_{2} \mathrm{O} . T=1223 \mathrm{~K}$.

Continuous lines: experimental curves; dashed lines: model predictions 

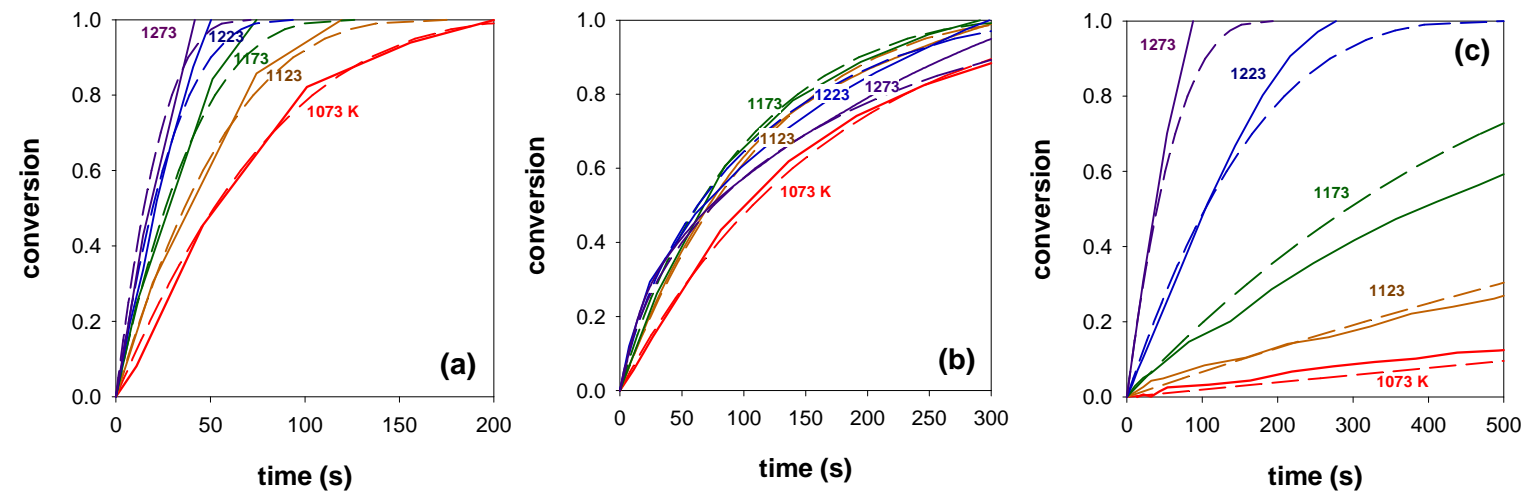

Figure 6. Effect of reacting temperature on the reduction reaction of Tierga iron ore for (a) 5 vol $\% \mathrm{H}_{2}+20$ vol $\% \mathrm{H}_{2} \mathrm{O}$, (b) 5 vol $\% \mathrm{CO}+20$ vol $\% \mathrm{CO}_{2}$ and (c) 5 vol $\% \mathrm{CH}_{4}+20$ vol $\% \mathrm{H}_{2} \mathrm{O}$. Continuous lines: experimental curves; dashed lines: model predictions 


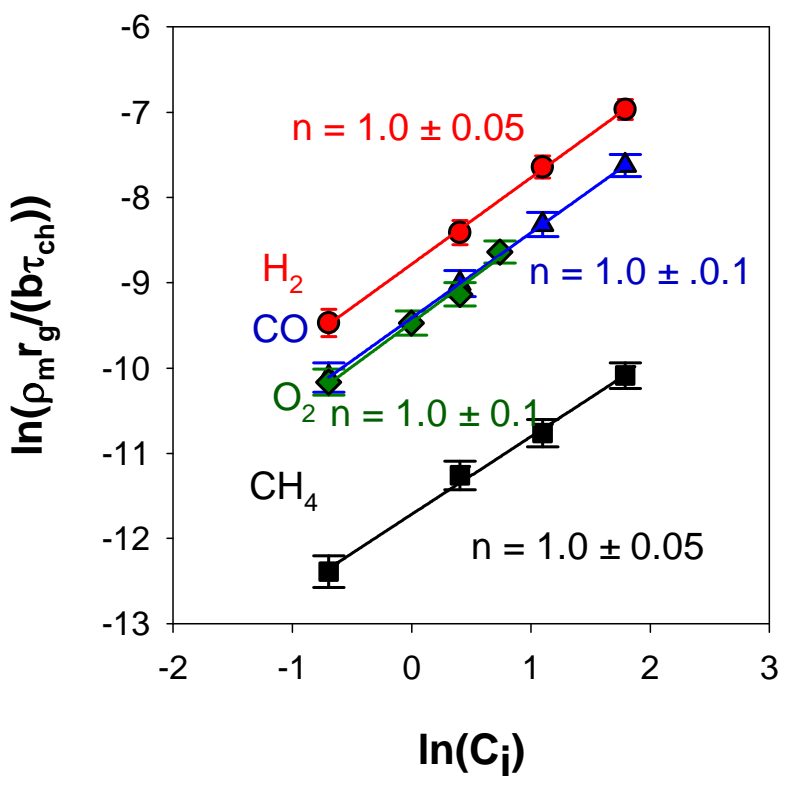

Figure 7. Plot to obtain the reaction order with respect to $\mathrm{H}_{2}, \mathrm{CO}, \mathrm{CH}_{4}$ and $\mathrm{O}_{2}$ for Tierga iron ore particles. The figure shows the values in a confidence interval $95 \%$ considering five redox cycles. 

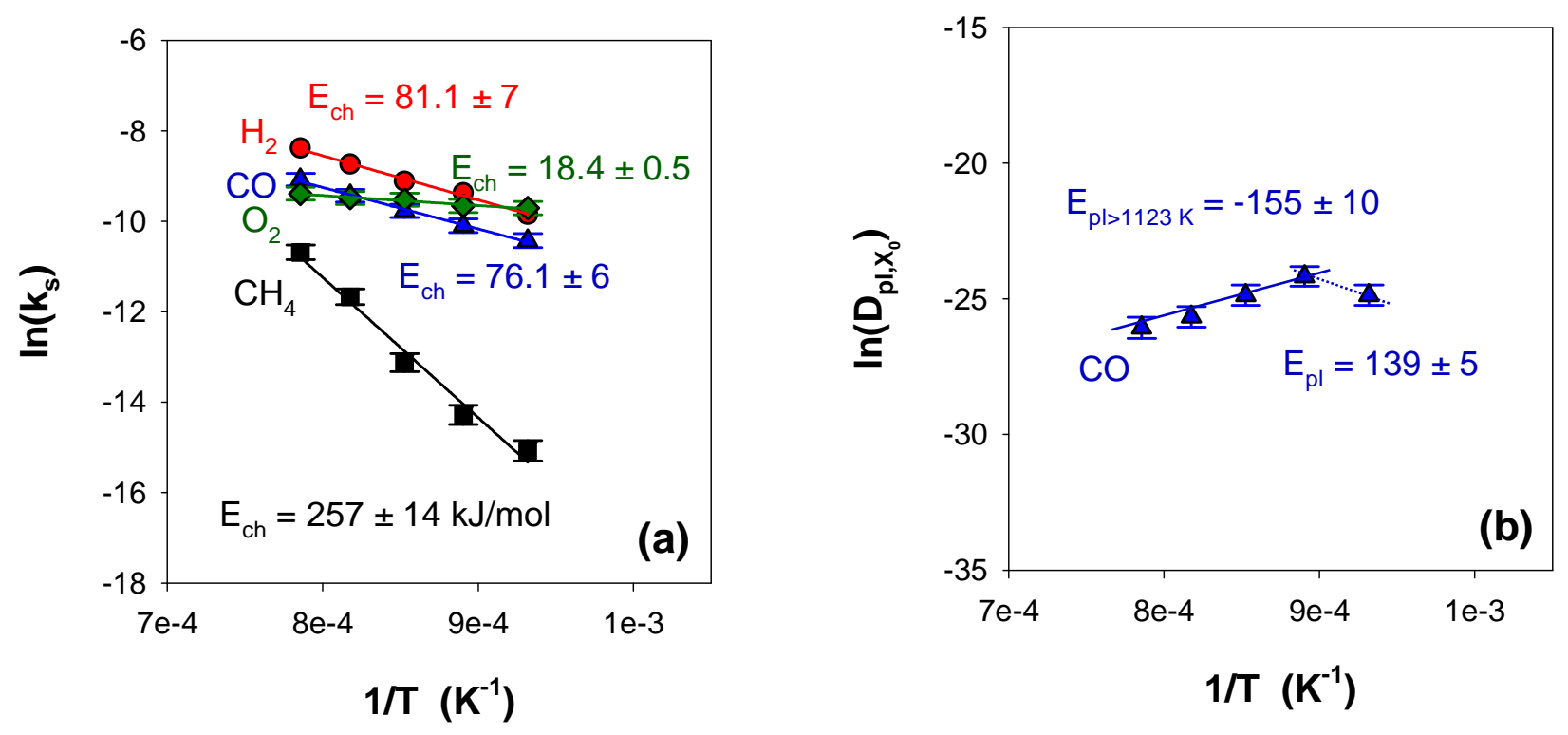

Figure 8. Arrhenius plot for the reaction of $\mathrm{H}_{2}, \mathrm{CO}, \mathrm{CH}_{4}$ and $\mathrm{O}_{2}$ with Tierga iron ore for (a) the kinetic constant, $k_{s}$ and (b) the diffusion coefficient, $D_{p l}$, for CO. The figure shows the values in a confidence interval 95\% considering five redox cycles. 


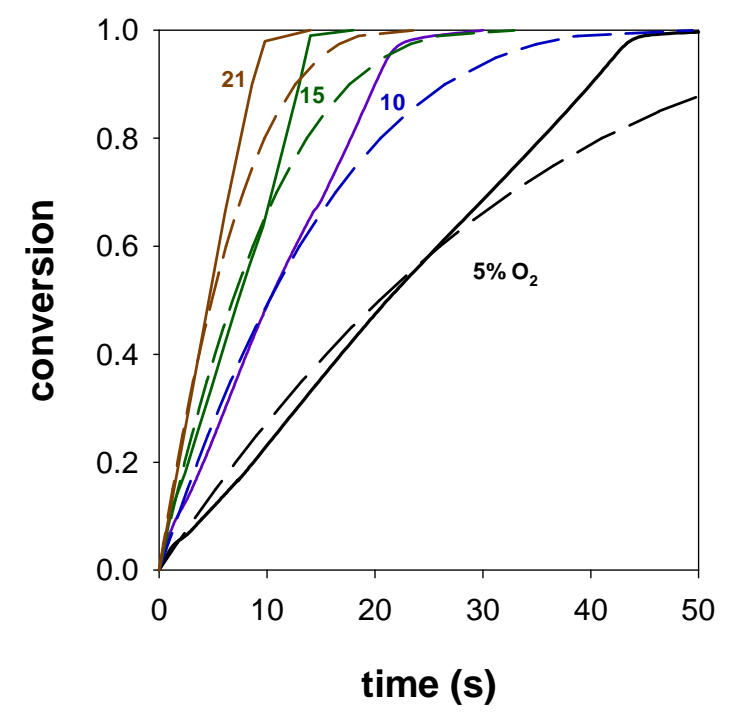

Figure 9. Effect of $\mathrm{O}_{2}$ concentration on the oxidation reaction for Tierga iron ore. $\mathrm{T}=1223$ K. Continuous lines: experimental curves; dashed lines: model predictions 


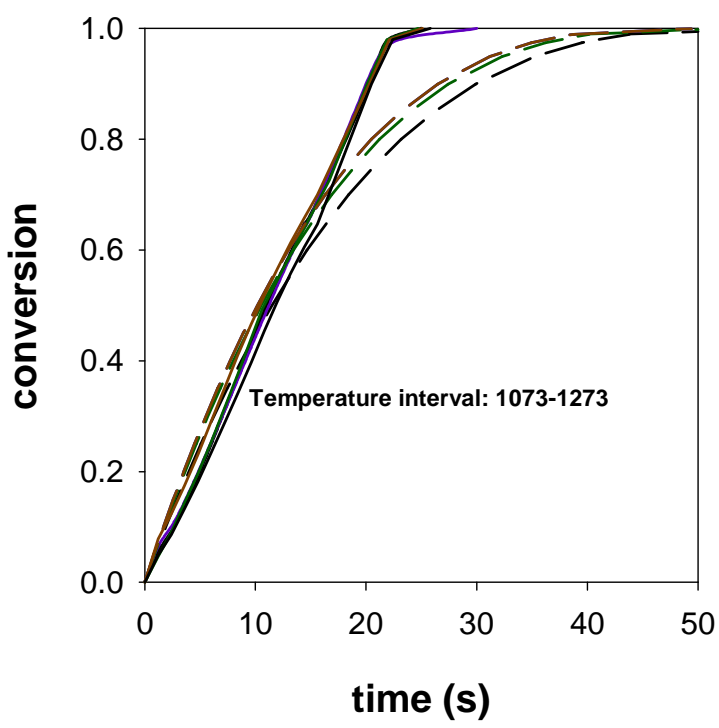

Figure 10. Effect of temperature on the oxidation reaction for Tierga iron ore. $10 \mathrm{vol} \% \mathrm{O}_{2}$. Continuous lines: experimental curves; dashed lines: model predictions 


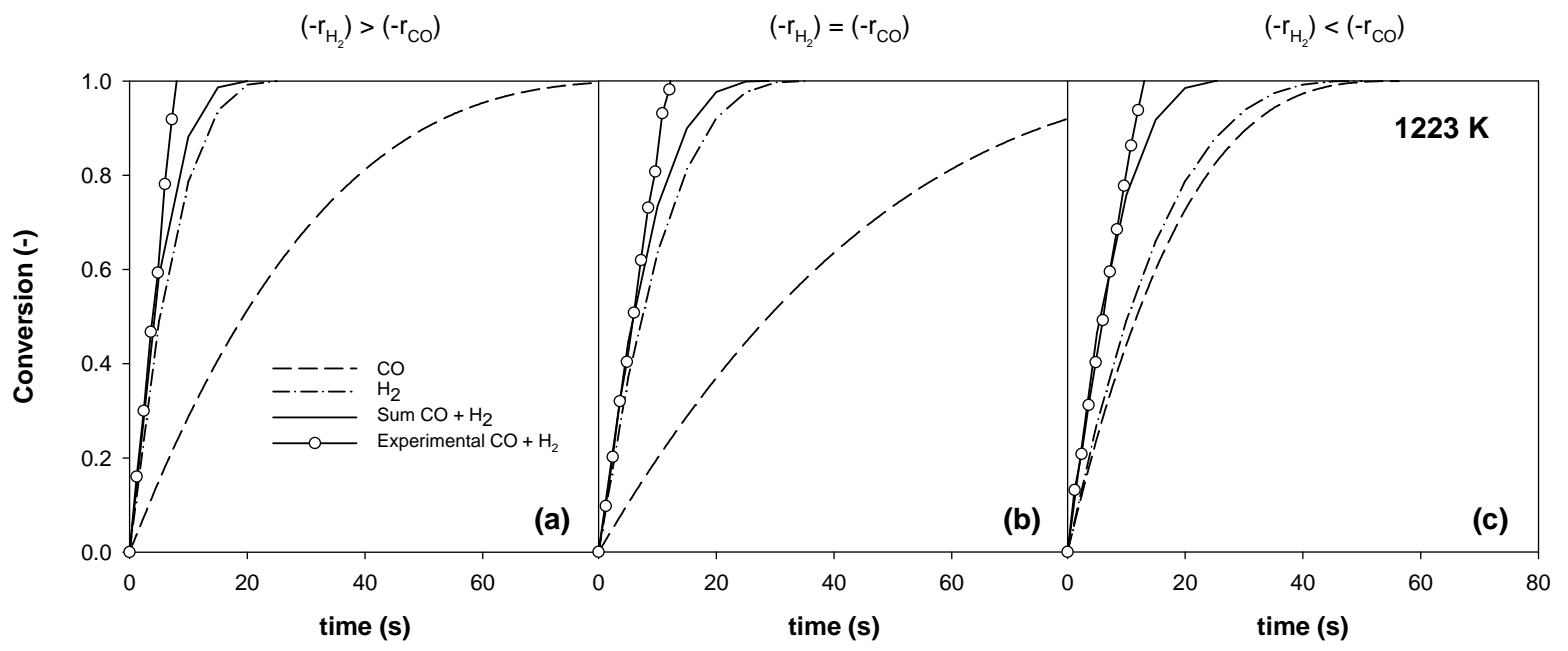

Figure 11. Conversion vs time curves for $\mathrm{H}_{2}$ and $\mathrm{CO}$ mixtures with Tierga iron ore at $\mathrm{T}=1223 \mathrm{~K}$. Conditions: (a) $10 \% \mathrm{CO} 20 \% \mathrm{H}_{2} 35 \% \mathrm{H}_{2} \mathrm{O} 11 \% \mathrm{CO}_{2} 24 \% \mathrm{~N}_{2}$ (b) $15 \% \mathrm{CO} 15 \%$ $\mathrm{H}_{2} 30 \% \mathrm{H}_{2} \mathrm{O} 18 \% \mathrm{CO}_{2} 22 \% \mathrm{~N}_{2}$ (b) $30 \% \mathrm{CO} 10 \% \mathrm{H}_{2} 20 \% \mathrm{H}_{2} \mathrm{O} 35 \% \mathrm{CO}_{2} 5 \% \mathrm{~N}_{2}$ 


\section{Tables}

Table 1. Main physical and chemical characteristics of Tierga iron ore particles.

\section{Calcined $\quad$ After used $^{\mathrm{a}}$}

\begin{tabular}{|c|c|c|}
\hline XRD main phases & $\mathrm{Fe}_{2} \mathrm{O}_{3}, \mathrm{SiO}_{2}, \mathrm{CaO}, \mathrm{MgO}$ & $\mathrm{Fe}_{2} \mathrm{O}_{3}, \mathrm{SiO}_{2}$ \\
\hline $\mathrm{Fe}_{2} \mathrm{O}_{3}(\mathrm{wt} \%)^{\mathrm{b}}$ & 76.5 & 83.5 \\
\hline Oxygen transport capacity, $R_{O C},(\%)^{\mathrm{c}}$ & 2.5 & 2.8 \\
\hline Crushing strength $(\mathrm{N})$ & 5.8 & 5.0 \\
\hline Skeletal density $\left(\mathrm{kg} / \mathrm{m}^{3}\right)$ & 4216 & 4313 \\
\hline Porosity $(\%)$ & 26.3 & 15.4 \\
\hline Specific surface area, BET $\left(\mathrm{m}^{2} / \mathrm{g}\right)$ & 1.4 & 1.0 \\
\hline \multicolumn{3}{|c|}{${ }^{\mathrm{a}}$ Particles after $30 \mathrm{~h}$ coal combustion test in a $0.5 \mathrm{~kW}$ CLC unit } \\
\hline \multicolumn{3}{|c|}{${ }^{\mathrm{b}}$ Determined by reduction in TGA with $15 \mathrm{vol} \% \mathrm{H}_{2}$ at $1223 \mathrm{~K}$} \\
\hline
\end{tabular}


Table 2. Equilibrium constant for reduction with $\mathrm{H}_{2}$ and $\mathrm{CO}$ in the redox pairs $\mathrm{Fe}_{2} \mathrm{O}_{3} / \mathrm{Fe}_{3} \mathrm{O}_{4}$, $\mathrm{Fe}_{3} \mathrm{O}_{4} / \mathrm{Fe}_{0.947} \mathrm{O}$ and $\mathrm{Fe}_{0.947} \mathrm{O} / \mathrm{Fe}$ at $1223 \mathrm{~K}$.

\begin{tabular}{lll}
\hline & $\mathrm{K}_{\mathrm{eq}, \mathrm{H} 2}$ & $\mathrm{~K}_{\mathrm{eq}, \mathrm{CO}}$ \\
\hline $\mathrm{Fe}_{2} \mathrm{O}_{3} / \mathrm{Fe}_{3} \mathrm{O}_{4}$ & $8.1 \cdot 10^{4}$ & $5.4 \cdot 10^{4}$ \\
$\mathrm{Fe}_{3} \mathrm{O}_{4} / \mathrm{Fe}_{0.947} \mathrm{O}$ & 4.2 & 2.8 \\
$\mathrm{Fe}_{0.947} \mathrm{O} / \mathrm{Fe}$ & $6.4 \cdot 10^{-1}$ & $4.4 \cdot 10^{-1}$ \\
\hline
\end{tabular}


Table 3. Kinetic parameters determined for reduction and oxidation reactions of Tierga iron ore.

\begin{tabular}{|c|c|c|c|c|}
\hline & $\mathrm{H}_{2}$ & $\mathrm{CO}^{(\mathrm{a})}$ & $\mathrm{CH}_{4}$ & $\mathrm{O}_{2}$ \\
\hline$n(-)$ & $1.0 \pm 0.05$ & $1.0 \pm 0.1$ & $1.0 \pm 0.05$ & $1.0 \pm 0.1$ \\
\hline$k_{s, 0}\left(\mathrm{~mol}^{1-\mathrm{n}} \mathrm{m}^{3 \mathrm{n}-2} \mathrm{~s}^{-1}\right)$ & $4.74 \cdot 10^{-1}$ & $1.45 \cdot 10^{-1}$ & $7.45 \cdot 10^{5}$ & $4.71 \cdot 10^{-4}$ \\
\hline$E_{c h}(\mathrm{~kJ} / \mathrm{mol})$ & $81.1 \pm 7$ & $76.1 \pm 6$ & $257 \pm 14$ & $18.4 \pm 0.5$ \\
\hline$D_{p l, 0}\left(\mathrm{~m}^{2} \mathrm{~s}^{-1}\right)$ & -- & $9.16 \cdot 10^{-5}\left(1.99 \cdot 10^{-18}\right)$ & -- & -- \\
\hline$E_{p l}(\mathrm{~kJ} / \mathrm{mol})$ & -- & $139 \pm 5(-155 \pm 10)$ & -- & -- \\
\hline
\end{tabular}


Table 4. Rate index and minimum solid inventory data for activated ilmenite [28] and Tierga ore ( $\mathrm{kg}$ of solids per $\mathrm{MW}_{\text {th }}$ of fuel)

\begin{tabular}{|c|c|c|c|c|c|c|c|c|}
\hline & \multicolumn{4}{|c|}{ Activated ilmenite } & \multicolumn{4}{|c|}{ Tierga ore } \\
\hline & $\mathrm{H}_{2}$ & $\mathrm{CO}$ & $\mathrm{CH}_{4}$ & $\mathrm{Coal}^{\mathrm{a}}$ & $\mathrm{H}_{2}$ & $\mathrm{CO}$ & $\mathrm{CH}_{4}$ & $\mathrm{Coal}^{\mathrm{a}}$ \\
\hline Rate index $(\% / \mathrm{min})^{\mathrm{b}}$ & 7.9 & 2.5 & 5.0 & - & 16.1 & 8.1 & 3.0 & - \\
\hline $\bar{C}_{g}(\%$ of fuel $)$ & 14.5 & 19.2 & 5.3 & 5 & 14.5 & 14.5 & 5.3 & 5 \\
\hline \multicolumn{9}{|l|}{ Fuel reactor } \\
\hline $\mathrm{T}=1173 \mathrm{~K}$ & 66 & 189 & 461 & 253 & 47 & 83 & 1418 & 161 \\
\hline $\mathrm{T}=1223 \mathrm{~K}$ & 52 & 139 & 272 & 201 & 36 & 62 & 574 & 125 \\
\hline $\mathrm{T}=1273 \mathrm{~K}$ & 42 & 105 & 167 & 163 & 28 & 47 & 250 & 98 \\
\hline \multicolumn{9}{|l|}{ Air reactor $^{\mathrm{c}}$} \\
\hline $\mathrm{T}=1173 \mathrm{~K}$ & 39 & 33 & 47 & 52 & 70 & 59 & 84 & 92 \\
\hline $\mathrm{T}=1223 \mathrm{~K}$ & 37 & 31 & 44 & 49 & 69 & 59 & 84 & 92 \\
\hline $\mathrm{T}=1273 \mathrm{~K}$ & 35 & 30 & 42 & 46 & 70 & 59 & 84 & 92 \\
\hline
\end{tabular}

